
POTENTIAL APPLICATION OF A PRODUCTION PROCESS PATENTED BY JACK W. MCINTYRE

By

David E. Kvasnicka

FECEIVED

SEP 03 1993

August 1993

OSTI

Work Performed Under Jack McIntyre/DOE Contract No. DE-FG46-92R699202

For

Jack W. McIntyre

Fort Stockton, Texas

And

U.S. Department of Energy

Omice of Scientific and Technical Information (OSTI)

Oak Ridge, Tennessee

By

Geraghty \& Miller, Inc. Midland, Texas
DISCLAIMER

This report was prepared as an account of work sponsored by an agency of the United States Government. Neither the United States Gnvernment nor any agency thereof, nor any of their employees, makes any warranty, express or implied, or assumes any legal liability or responsibility for the accuracy, completeness, or usefulness of any information, apparatus, product, or process disclosed, or represents that its use would not infringe privately owned rights. Reference herein to any specific commercial product, process, or service by trade name, trademark, manufacturer, or otherwise does not necessarily constitute or imply its endorsement, recommendation, or favoring by the United States Goveınment or any agency thereof. The views and opinions of authors expressed herein do not necessarily state or reflect those of the United States Government or any agency thereof. 


\section{CONTENTS}

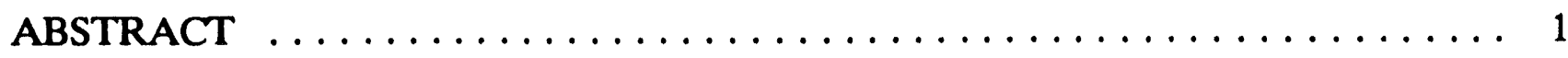

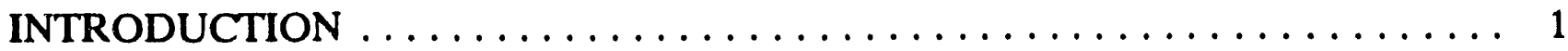

GEOLOGICAL SETTING $\ldots \ldots \ldots \ldots \ldots \ldots \ldots \ldots \ldots \ldots \ldots$

PRECAMBRIAN PERIOD $\ldots \ldots \ldots \ldots \ldots \ldots \ldots \ldots \ldots \ldots \ldots, 7$

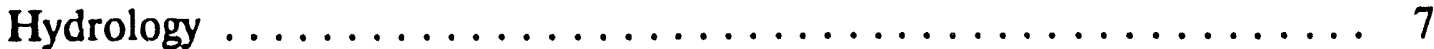

CAMBRIAN PERIOD $\ldots \ldots \ldots \ldots \ldots \ldots \ldots \ldots \ldots \ldots \ldots \ldots$

Hydrology ....................... 8

ORDOVICIAN PERIOD $\ldots \ldots \ldots \ldots \ldots \ldots \ldots \ldots \ldots \ldots, 8$

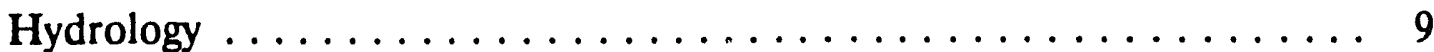

DEVONIAN PERIOD $\ldots \ldots \ldots \ldots \ldots \ldots \ldots \ldots \ldots \ldots \ldots$

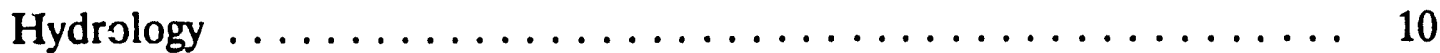

MISSISSIPPIAN PERIOD $\ldots \ldots \ldots \ldots \ldots \ldots \ldots \ldots \ldots \ldots \ldots \ldots, 10$

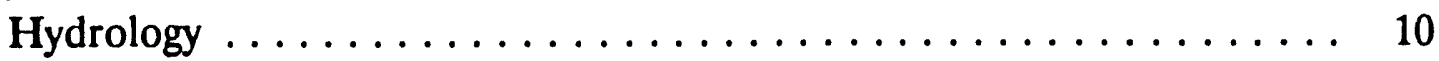

PENNSYLVANIAN PERIOD $\ldots \ldots \ldots \ldots \ldots \ldots \ldots \ldots \ldots \ldots \ldots \ldots, 10$

Hydrology ................................ 11

PERMIAN PERIOD $\ldots \ldots \ldots \ldots \ldots \ldots \ldots \ldots \ldots \ldots \ldots \ldots \ldots, 11$

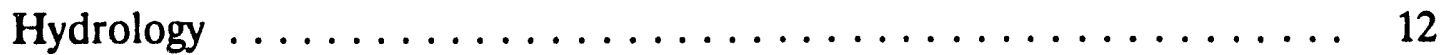

TRIASSIC PERIOD $\ldots \ldots \ldots \ldots \ldots \ldots \ldots \ldots \ldots \ldots \ldots \ldots \ldots, 12$

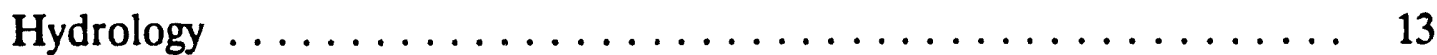

JURASSIC PERIOD $\ldots \ldots \ldots \ldots \ldots \ldots \ldots \ldots \ldots \ldots \ldots \ldots \ldots \ldots$

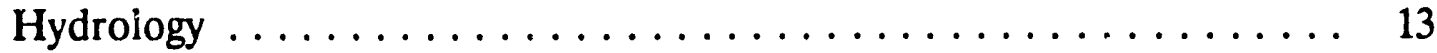

CRETACEOUS PERIOD $\ldots \ldots \ldots \ldots \ldots \ldots \ldots \ldots \ldots \ldots \ldots, 14$

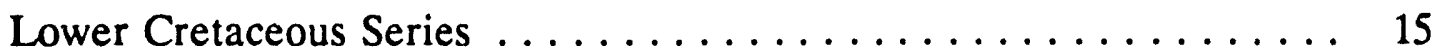

Upper Cretaceous Series ..................... 15

Hydrology ........................... 16

Palocene and Eocene Age Deposition ................ 19

PRINCIPAL COAL-BEARING STRATA $\ldots \ldots \ldots \ldots \ldots \ldots \ldots \ldots, 19$

Fort Union Formation $\ldots \ldots \ldots \ldots \ldots \ldots \ldots \ldots \ldots \ldots \ldots$

Tullock Member ......................... 19

Hydrology ........................ 20

Lebo Shale Member ...................... 20

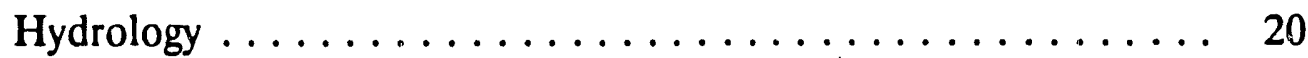

Tongue River Member .................... 24

Wasatch Formation ....................... 25

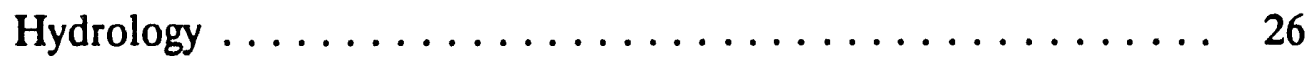

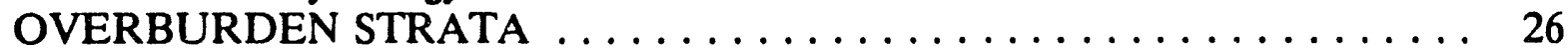




\section{CONTENTS cont'd}

COAL AND COALBED METHANE - OCCURRENCE, QUANTITY IN-PLACE AND CHEMICAL CHARACTERISTICS $\ldots \ldots \ldots \ldots \ldots \ldots \ldots \ldots, 26$

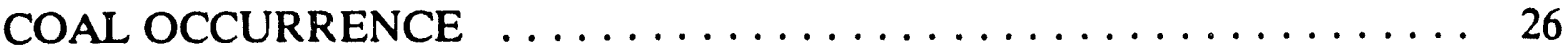
ESTIMATE OF COALBED METHANE RESERVES $\ldots \ldots \ldots \ldots \ldots 28$ PRODUCTION OF COALBED METHANE FROM TERTIARY-AGE COALS .......................... 30

AQUIFER AND RESERVOIR DISTRIBUTION $\ldots \ldots \ldots \ldots \ldots \ldots \ldots \ldots$

FORMATIONS ACCEPTING DISPOSAL OF PRODUCED WATER . . . . . 39

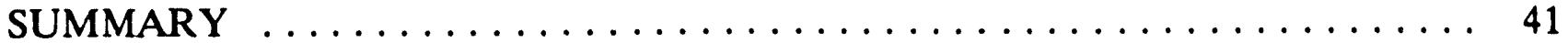

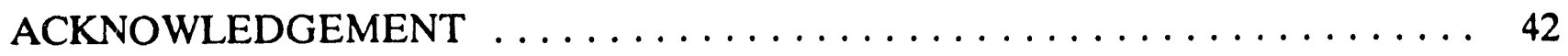

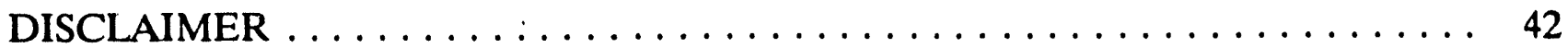

REFERENCES $\ldots \ldots \ldots \ldots \ldots \ldots \ldots \ldots \ldots \ldots \ldots \ldots \ldots \ldots \ldots \ldots \ldots$ 


\title{
GEOHYDROLOGIC FEASIBILITY STUDY OF THE POWDER RIVER BASIN FOR THE POTENTIAL APPLICATION OF A PRODUCTION PROCESS PATENTED BY JACK W. MCINTYRE
}

\begin{abstract}
Geraghty \& Miller, Inc. of Midland, Texas conducted geologic and hydrologic feasibility studies of the potential applicability of a patented (U.S. Patent Office \# $4,766,957)$ process developed by Jack W. McIntyre for the recovery of natural gas from coalbed/sand formations in the Powder River Basin. General research, based on a review of published literature from both private and public sources, indicates that the shallow, thick subbituminous coal seams found in the Powder River Basin exhibit significant potential for the application of this patented process.

These coal deposits can be characterized, on the basis of established coalbed methane production, as being highly water productive. The desorption and economic recovery of coalbed methane, widely believed to be biogenic in origin, from these low-grade deposits will require the subsequent dewatering of these geologic formations. The patented process, developed by Mr. McIntyre and described in the compendium of this study, may offer a cost-effective means of methane recovery and downhole disposal of produced groundwaters.
\end{abstract}

\section{INTRODUCTION}

The Powder River Basin area of northeastern Wyoming and southeastern Montana (Figure 1) contains an estimated 1.0 trillion tons of coal in deposits at depths of 2,500 feet or less. The Tongue River member of the Fort Union Formation may contain as much as 103 trillion cubic feet (TCF) of coalbed methane. A total of twenty producing fields had been established by August of 1990, with a total of 90 wells having produced over 3.3 billion cubic feet of coalbed methane. During the first six months of 1992, 32 additional wells were staked to be drilled in the Powder River basin. Of these, 17 were brought into production, 

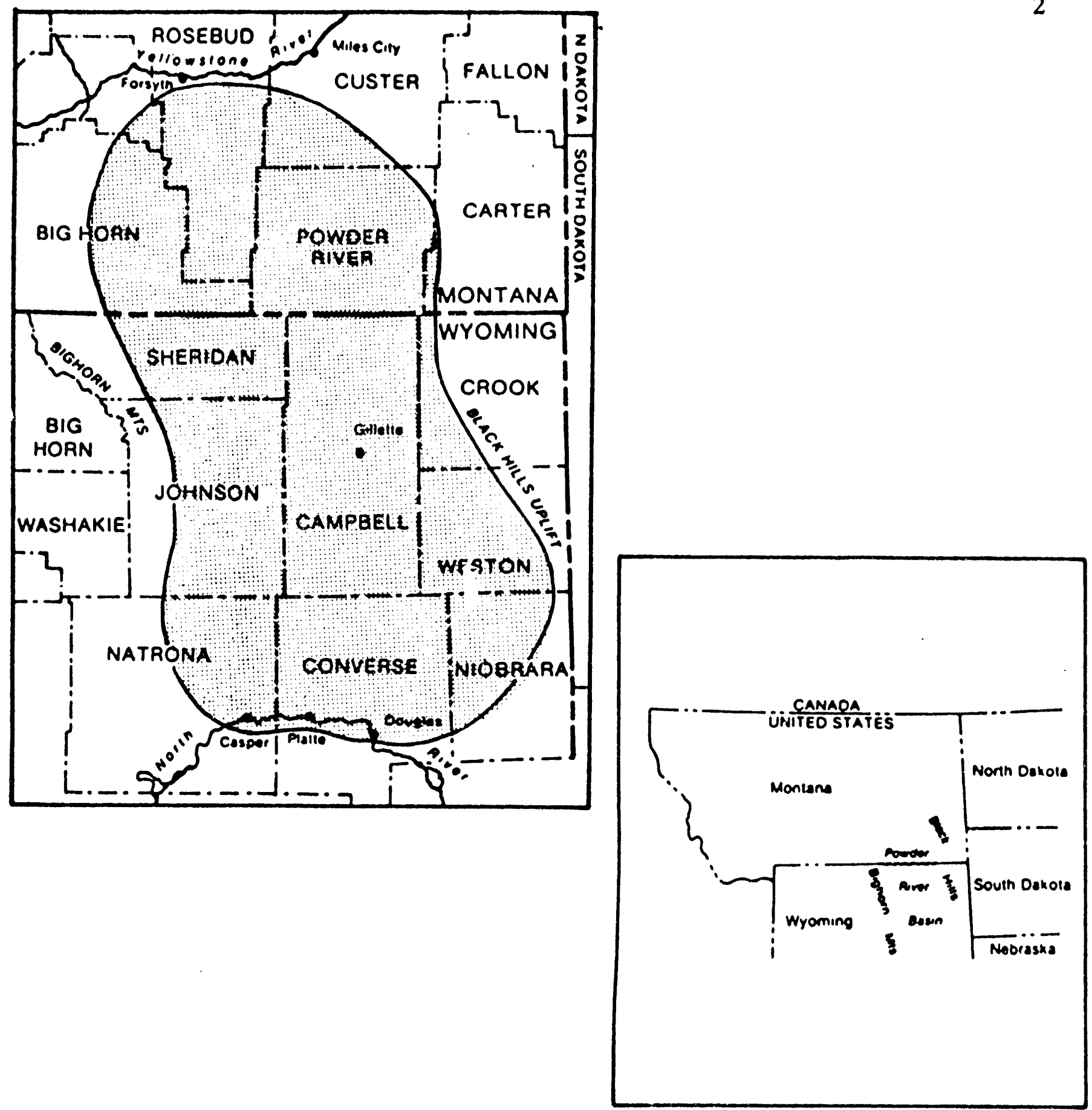

Figure 1. Index Maps showing location of Powder River Basin and Showing Powder River Basin in relation to geographic and cultural features. (from Choate et al. 198, 
and no information was found on the remaining 15 staked locations (Gas Research Institute Quarterly Review July 1992).

Water production associated with recovery of coalbed methane in the basin is largely associated with producing wells in three field areas. These are the Rawhide Butte (19 wells; 643,119 barrels of water), Dead Horse Creek (6 wells SHUT IN; 659,058 barrels) and an unnamed field (1 well SHUT IN; 434,782 barrels). Many active producing wells are completed in sandstone adjacent to coal seams, and water production from these wells has been negligible.

A new process patented by Jack W. McIntyre has both economic and environmental advantages over the conventional surface treatment and disposal. This process has been tested in the Michigan Basin and reported to be successful. The process is based on utilizing a single well for both production and water disposal. During production, fluids enter the wellbore, gas rises to the surface and water moves down into the disposal zone either by gravity or mechanical pumping. This method allows separation of gas with simultaneous disposal of the water without the economic and environmental obstacles of bringing the water to the surface. A description and discussion of Jack W. McIntyre's process is summarized in the compendium of the seven basins studied under this contract.

The objective of this investigation was primarily to identify the geologic and hydrologic parameters associated with the production of coalbed methane in the Powder River Basin for the potential use of Mr. McIntyre's patented production process. The investigation includes the description of geologic formations in ascending order, the presentday structure of each formation, the stratigraphy of each formation as it applies to potential methane gas production and disposal, hydrologic conditions (formation pressure, fluid chemistry, etc) and reservoir and production history. Published papers and reports were the primary sources of information utilized for this investigation. No field acquisition of data was performed during this investigation, and it does not include testing of Mr. Mclntyre's production process in the Powder River Basin. 


\section{GEOLOGICAL SETTING}

The Powder River Basin was formed through compressional deformation, associated with the Laramide orogeny, which occurred in late-Cretaceous through early-Tertiary time. The sedimentary section has a maximum gross interval thickness of over 18,000 feet (Figure 2). The basin is a broad, asymmetric, structural feature with a north/south trending axis located near the western margin (Figure 3 ) and is bounded by major structural uplifts which include the Black Hills (east), the Hartville (southeast) and the Bighorn mountains (west). In addition, the Laramie Mountains and the Casper Arch border the Powder River Basin on the southwest perimeter.

Regional dip is very slight across the easternmost third of the basin, averaging two to three degrees. Sediments are nearly flat lying through the deep basin. Regional dip is much more pronounced westward beyond the basin axis and along the eastern flank of the Bighorn Mountains where dips range from 10 to 25 degrees (Mapel 1958).

The Powder River Basin is a regional synclinal feature whose structural genesis is related to similar basins along the front range of the Rocky Mountains. Of these basins, the Powder River Basin is the deepest. Numerous anticlinal features, primarily cumpression folds, have been identified within the basin. Theses folds account for most of the structural traps within the basin. Faulting is primarily associated with the western basin margin, specifically the Buffalo deep fault (Blackstone 1981) along the base of the Bighorn Mountains. The Buffalo Fault was formed in late-Paleocene time, probably during deposition of the Tongue River Member of the Fort Union Formation during uplift of the Bighorn Mountains. 


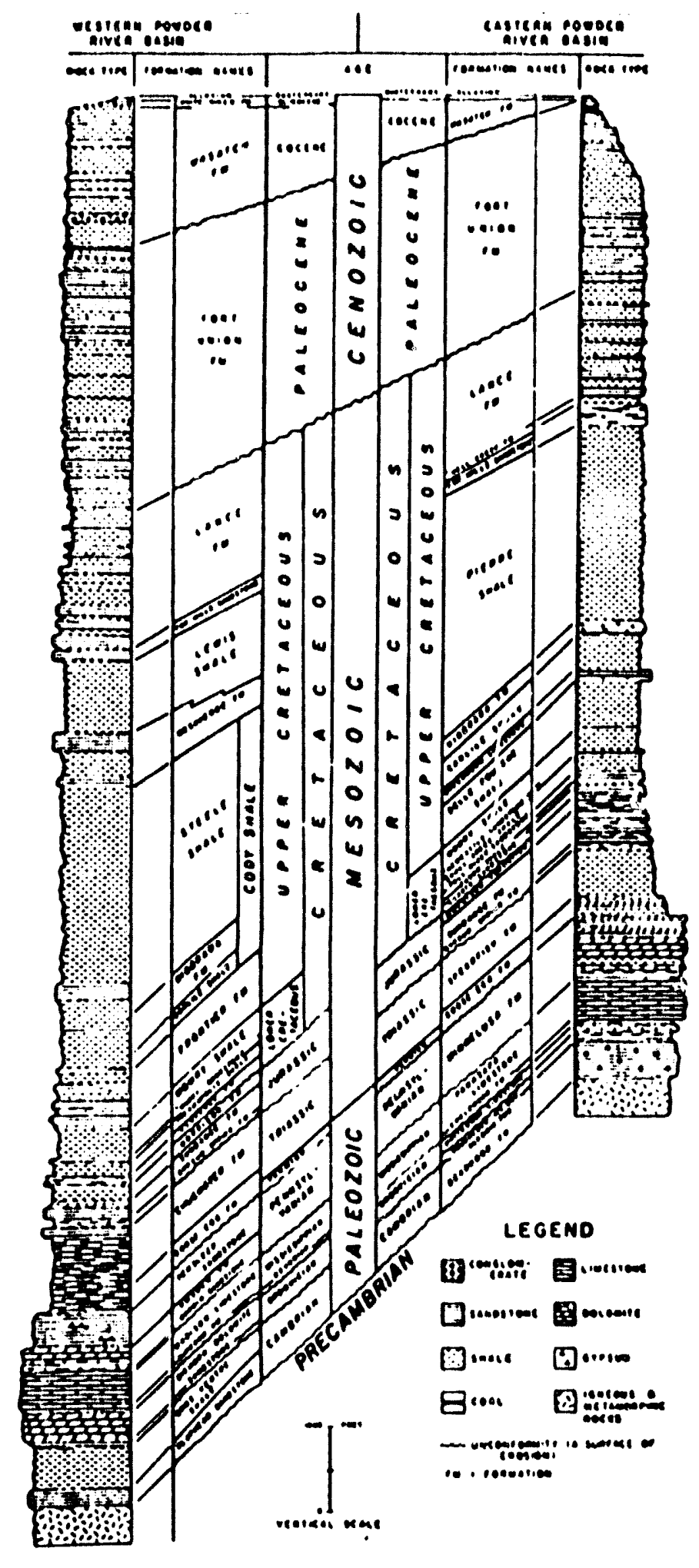

Figure 2. Representative stratigraphic columns for the Powder River Basin, Wyoming. Breckenridge et al, 1974. (from Choate et al, 1984). 


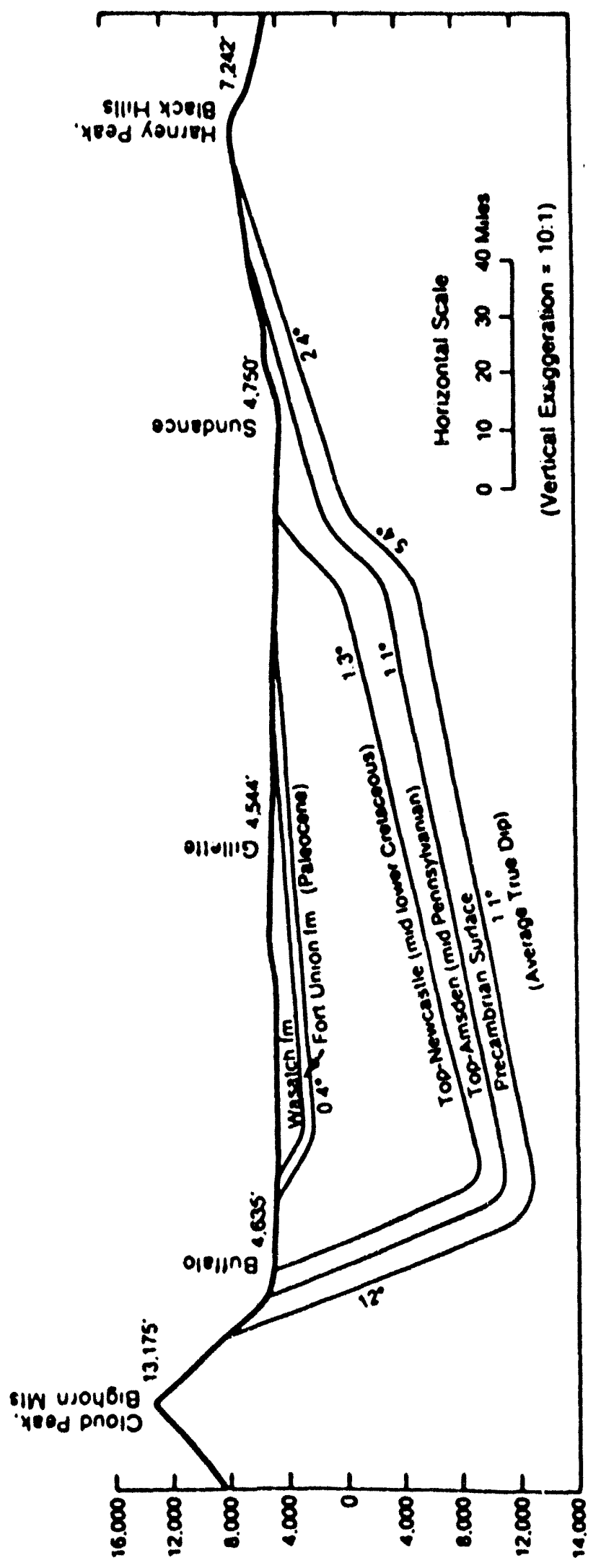

Figure 3. East-west section across Powder River Basin showing slightly tilted, trough-like structure in older sedimentary rocks. (from Choate et al, 1984) 
The Powder River Basin contains thick accumulations of Paleozoic and Mesozoic sediments which are largely marine in origin. These deposits are overlain by a relatively thin accumulation of late-Cretaceous and Cenozoic sediments derived principally from continental source areas.

\section{PRECAMBRIAN PERIOD}

The Precambrian period is represented by igneous and metamorphic basement rocks consisting of granite, gneiss and schist. These rocks form the core of the Bighorn Mountains to the west of the Powder River Basin and are also found in association with intrusive rocks of Tertiary-age in the Black Hills Uplift to the east (Hodson et al 1973).

\section{Hydrology}

Groundwater is found in fractures, joints and weathered zones associated with local outcrops. Yields up to 20 gallons per minute (gpm) are known. Dissolved solids are generally below 100 milligrams per Liter $(\mathrm{mg} / \mathrm{L})$, and the dominant water chemistry is calcium bicarbonate (Hodson et al 1973).

\section{CAMBRIAN PERIOD}

Deposition of sediment during the Cambrian period is associated with the slow, eastward progradation of an inland sea. The area known today as the Powder River Basin was dry land in early Cambrian time and, as a result, deposition of marine sediments did not occur during the Lower Cambrian.

The Middle Cambrian section is represented in the western basin area by the Flathead Sandstone. The Flathead is up to 340 feet thick in northern Johnson County and thins to the south to an average thickness of 90 feet in the southern basin. Middle 
Cambrian deposition did not occur in the eastern portion of the ancestral basin (Hodson et al 1973).

\section{Hydrology}

The Flathead produces groundwater from near-surface weathered deposits along the eastern flank of the Bighorn Mountains and yields up to $20 \mathrm{gpm}$. Average total dissolved solids is reported to be less than $500 \mathrm{mg} / \mathrm{L}$. Water chemistry is dominated by calcium bicarbonate (Hodson et al 1973).

The Upper Cambrian occurs in the western basin as the Gros Ventre and Gallatin Formations and in the east as the Deadwood Formation. The combined thickness of the Gros Ventre and Gallatin formations ranges from 600 feet in northern Johnson County to non-existent along the southern basin. The Deadwood thins southward from about 500 feet in northern Crook County to approximately 200 feet near Newcastle. Deposition of the Deadwood is not known in the southeast portion of the basin (Hodson et al 1973).

Groundwater is scarce in the Gros Ventre and Gallatin formations and yields are less than $10 \mathrm{gpm}$. Water chemistry is not documented. The occurrence of groundwater in the Deadwood Formation is not well documented; however, a flowing well completed at a depth of 6,227 feet has been identified in the northwest quarter of T $44 \mathrm{~N}, \mathrm{R} 62 \mathrm{~W}$, near the eastern perimeter of the Powder River Basin. Total dissolved solids are in excess of 2,000 $\mathrm{mg} / \mathrm{L}$ and the dominant water chemistry is calcium sulfate (Hodson et al 1973).

\section{ORDOVICIAN PERIOD}

Deposition during the Ordovician period was limited to the northern portion of the ancestral Powder River Basin due to the northward regression of the marine environment into the Williston Basin to the northeast (McCoy 1958). The greatest overall thickness of Ordovician-age rocks is found in the northwest portion of the basin. The Bighorn Dolomite, 
which includes a basal sandstone member, lies unconformably above Cambrian age sediments. The Bighorn thins southward from 430 feet in Sheridan County to approximately 150 feet in central Johnson County. The formation is absent further south. Along the east side of the basin, dolomites, siltstones and shales were deposited and are identified in literature as the Whitewood Dolomite and the Winnepeg Formation. The maximum combined thickness of these Bighorn correlative units is 100 feet (Hodson et al 1973).

\section{Hedrology}

Groundwater is produced from the Bighorn Dolomite from solution cavities and fractures in and near outcrops. Documentation of groundwater production and quality is poor for the Bighorn and no information was found regarding groundwater in the Whitewood and Winnepeg formations (Hodson et al 1973).

\section{DEVONIAN PERIOD}

Deposition of marine sediments during the Devonian Period was restricted to the eastern margin of the Powder River Basin. The Englewood Limestone is a thin-bedded unit with an average thickness of approximately 50 feet. Due to surface erosion which occurred in the Powder River Basin area during Devonian time, preserved rocks are unconformably bedded over Ordovician-age rocks and below Mississippian-age rocks. Terrestrial deposition

did not occur ir. the Powder River Basin in Devonian time. Deposition of the Englewood Formation continued into early Mississippian time. It has been suggested (Jenkins and McCoy 1958, pg 33) that the lowermost sediments of the Guernsey Formation may be the stratigraphic equivalent of the Englewood in the southeast portion of the Powder River Basin. The Guernsey Formation is principally described as being Lower Mississippian in age (Hodson et al 1973). 
Hydrology

Groundwater is not associated with the Englewood Limestone (Hodson et al 1973).

\section{MISSISSIPPIAN PERIOD}

The Lower Mississippian series of the Powder River Basin is represented by the Madison Limestone in the west and the Guernsey Formation and Pahasapa Limestone in the east. The section thickens to the north in Montana, where the stratigraphic nomenclature includes the names of three Madison-equivalent units. These are, in ascending order, the Lodgepole and Mission Canyon limestones and the Charles Formation. The Mississippian section thins toward the south with grcss interval thickness decreasing from greater than 2,000 feet in Montana to approximately 200 feet near the southern end of the Powder River Basin (Hodson et al 1973).

\section{Hydrology}

Production of groundwater from the Madison and Pahasapa limestones indicates well yields which exceed 1,000 gpm. Several flowing wells located in northeast Natrona County, Wyoming have yields ranging from 25 to $9450 \mathrm{gpm}$ and are completed at an average depth of 5,000 feet. The water is of a sodium sulfate type and total dissolved solids ranged from 1,560 to $3,240 \mathrm{mg} / \mathrm{L}$. These wells lie within 50 miles of the western outcrop belt, and water quality may reflect the relative proximity of active recharge. The Madison and equivalent formations can be found at substantially greater depths in the basin, and water quality in these formations is not known in the basin interior (Hodson et al 1973).

\section{PENNSYLVANIAN PERIOD}

Deposition during the Pennsylvanian Period began with subsidence of the ancestral Powder River Basin in late-Mississippian time. The Amsden Formation, along with the 
basal Darwin Sandstone, was deposited in the northwest portion of the basin during an extended period of transgressing seas. The total thickness of the Amsden Formation thins from 250 feet in the northern Powder River Basin to completely absent in the southern basin (Hodson et al 1973).

The Amsden Formation is overlain by the Tensleep Sandstone in the northwest and central basin. The Hartville and Minnelusa formations are correlative units deposited in the south and east portior.s of the Powder River Basin. The Tensleep Sandstone thickens to the south and total thickness ranges from approximately $50 \mathrm{feet}$ in the northern basin to as much as 500 feet in the south and southwest portions of the basin. The Hartville and Minnelusa formations are found only in the southeast part of the basin with each 800 to 1,000 feet in total thickness (Hodson et al 1973).

\section{Hydrology}

Groundwater associated with the Amsden Formation is not widely documented and production appears to be in close proximity to outcrops. Documented production of groundwater resources from the Tensleep has been in the western portion of the basin in proximity to the outcrop area (Hodson et al 1973).

\section{PERMIAN PERIOD}

Near the end of Pennsylvanian time, several broad, gentle, northeast-trending folds developed in the northeastern part of the area, and an erosional unconformity separates marine Pennsylvanian rocks from brackish-water and evaporitic Permian rocks. Permian strata consist regionally of redbed and evaporitic facies with some halite beds in the western part of the area (Baars et al. 1988).

Although largely deposited during Pennsylvanian time, the Tensleep, Hartville and Minnelusa formations extend into earliest Permian time and thus provide a basis for 
description of Permian sedimentation. These three formations have been addressed in the discussion of Pennsylvanian deposition.

The preserved Permian section generally thickens toward the southwest part of the basin. The Goose Egg Formation, and its equivalents in the northwestern portion of the basin, consist of interbedded red shale, gypsum and thin-bedded limestone. The Goose Egg Formation reaches a maximum thickness of 350 feet in the southwest part of the basin and is approximately 180 feet thick in the Buffalo-Lake De Smet area (Hodson et al 1973).

Permian sediments are substantially thinner in the eastern part of the Powder River basin. The Opeche Shale of lower Permian age has a maximum reported thickness of 120 feet in the Black Hills (Bropst and Epstein 1963) and thins to the southeast with thicknesses ranging from 25 to 75 feet (Denson et al. 1949). The Minnekahta Limestone (middle to upper Permian age) is composed of thin-bedded limestone and dolomitic limestone. The interval thickness is generally less than $\mathbf{5 0}$ feet across the eastern part of the basin.

\section{Hydrology}

Groundwater resources are limited in Permian-age rocks and when present are known to be of very poor quality, being dominated by sodium chloride and having total dissolved solids in excess of $30,000 \mathrm{mg} / \mathrm{L}$ (Hodson et al 1973).

\section{TRIASSIC PERIOD}

Deposition of redbeds and evaporites continued throughout the Triassic Period. In the western basin, the Chugwater Formation, consisting of dark-red siltstone, sandstone and shale, was deposited with total thicknesses of 700 to 800 feet. In the east, the Spearfish Formation, composed of red shale, siltstone, sandstone and gypsum, was deposited in thicknesses ranging from 450 feet near Newcastle, Wyoming to 825 feet in northwest Crook County (Robinson et al. 1964). 


\section{Hydrology}

As with the Permian-age sediments described earlier, groundwater resources are not widespread and generally exhibit poor chemical quality (Hodson et al 1973).

\section{JURASSIC PERIOD}

Sediments deposited during late Triassic and early Jurassic time were removed through erosion related to tectonic activity in the vicinity of the incipient Powder River Basin. Middle Jurassic deposition remained very similar to both the Triassic and Permian Periods and included anhydrite, gypsum and redbeds which occupy the northern third of the present basin. The southernmost extent of these deposits is no longer evident as, once again, tectonic activity in the area permitted erosion of sediments in the southern portion of the basin. The middle Jurassic Period is represented by the Gypsum Spring Formation, which can be found across the northern portion of the present Powder River Basin. The Gypsum Spring is made up of deposits of massive gypsum, red claystone and gray limestone in the east and primarily red shale and claystone in the west. Where it is found, this formation ranges in thickness from 125 to 185 feet (Hodson et al 1973).

\section{Hydrology}

Groundwater is present and some use for stock purposes is known. Pumping discharge is only a few gallons per minute and total dissolved solids are generally more than $1,000 \mathrm{mg} / \mathrm{L}$ (Hodson et al 1973).

The Gypsum Spring Formation is overlain by the Sundance Formation which consists of greenish-gray shale and interbedded fine-grained sandstone. These sediments were deposited in a marginal marine environment influenced by a westward-trending structural feature known as the Sheridan Arch, which was roughly coincident with the present state line between Wyoming and Montana. 
Following deposition of the Gypsum Spring Formation, the Jurassic sea transgressed further to the south. By late Jurassic time, the seas had once again retreated to the north and non-marine deposition of lenticular sandstones and claystones followed. The Morrison Formation was deposited in a lacustrine environment. The sandstones are most commonly found within the lower Morrison and individual sand lenses are seldom more than 6 feet thick and are frequently discontinuous. Cross bedding and ripple marks are also common.

Groundwater supplies derived from the Morrison are very limited in quantity. An average well may yield as much as 10 gallons per minute; however, the yield for a given well is dependent upon the number and thickness of sandstone beds encountered by the well bore. The water is of the sodium sulfate type with a relatively low concentration of dissolved solids.

\section{CRETACEOUS PERIOD}

Near the close of the Jurassic Period, the sedimentary environment of the incipient Powder River Basin returned to a marine setting as broad inland seas, characteristic of the Cretaceous Period, swept across the area. These seaways were forced into periodic retreat as regional tectonic activity became increasingly prevalent with the beginnings of the Laramide orogeny in late-Cretaceous time.

The Cretaceous section contains the thickest sedimentary sequence of any depositional period preserved within the present Powder River basin. The maximum gross interval thickness is nearly 7,000 feet in the western basin and in excess of 6,000 feet in the eastern region (Hodson et al 1973). A total of eighteen different formations have been identified as having been deposited during Cretaceous time. The present discussion shall address the Lower Cretaceous and the Upper Cretaceous sections as collective portions of the complete series. 


\section{Lower Cretaceous Series}

The sediments of the lower Cretaceous series are entirely marine in origin and, in the western part of the present basin, consist of shale with some interbedded siltstones and occasional thin sandstones. Of the sandstone members found in the Lower Cretaceous, the Muddy Sandstone is perhaps the most notable. The Muddy Sandstone member of the Thermopolis Shale is a medium-grained sandstone with some interbedded shale which extends across the basin to the eastern portion of the basin, where it is correlative to the Newcastle Sandstone. The Muddy Sandstone member is a recognized producer of oil and gas across the Powder River Basin as well as in other parts of the region. Other clastic formations found within the Lower Cretaceous section of the eastern Powder River basin include the Lakota and Fall River sandstones. The Lakota is often conglomeratic, although clastic deposition within the predominant shale framework is lenticular and very discontinuous. The Fall River is very similar with finer-grained sandstone, interbedded shales and siltstone. The Lower Cretaceous series is concluded with the deposition of the Mowry Shale. The Mowry Shale is thin-bedded and siliceous and is found to attain maximum thickness of 525 feet near the Buffalo-Lake De Smet area (Mapel 1959).

This formation commonly exhibits a siliceous character and is generally quite brittle. This characteristic may enhance the likelihood of secondary permeability within the formation which could influence the transmissivity of groundwater into producing water wells.

\section{Upper Cretaceous Series}

Deposition within the Upper Series very closely resembles that of the Lower Series. Much of the Upper Cretaceous is predominantly shale with only local lenses of sand. In the western portion of the present Powder River basin, the Frontier Formation is sandstone and interbedded shale. The sandstone is conglomeratic near the top of the formation and sand is more prevalent throughout the formation toward the south. 


\section{Hydrology}

The Frontier Sandstone is an important aquifer in the southwestern portion of the basin and many flowing stock wells completed at depths approaching 1,000 feet have yields ranging from 1 to 10 gallons per minute. Water chemistry is generally dominated by either sodium sulfate or sodium bicarbonate (Hodson et al 1973).

The Laramide orogeny began in late-Cretaceous time and, with the subsequent upsurge in tectonic activity, the marine depositional environment was forced to retreat one last time from the area of the present Powder River Basin. The introduction of terrigenous sedimentation to the area resulted in the significant accumulation of clastic materials, and the formation of numerous swamps across exposed deltaic plains dissected by fluvial channels and small lakes. This environment would predominate within the Powder River Basin area throughout the remainder of the preserved geologic record.

The Mesaverde Formation was deposited during an extended period of marine transgression and regression and consists of interbedded marine and terriginous deposits. In the western portion of the Powder River Basin, the Mesaverde contains three members, the lower or Parkman sandstone member, an unnamed intermediate marine shale and the

overlying Teapot sandstone member. The Parkman has yielded dinosaur remains and petrified wood, suggesting a non-marine depositional setting. This suggestion is further enhanced by the presence of coal within the Parkman sandstone member. The total thickness of the Mesaverde is about 850 feet near Salt Creek, Wyoming and thins to 280 feet near the type locality of the Parkman member, found near Parkman, Wyoming (Hodson et al 1973).

Groundwater resources are associated with the Mesaverde, which is known to yield as much as 50 gallons per minute from sandstone beds and up to 200 gallons per minute where permeability has been enhanced by fracturing, such as near geologic structures. Total dissolved solids are generally within the range of 300 to over $2,000 \mathrm{mg} / \mathrm{L}$. The water chemistry is dominated by sodium sulfate (Hodson et al 1973). 
Development of coal resources within the Mesaverde is very limited within the Powder River Basin, due in large part to depth of burial and gross interval thickness relative to overlying strippable coai deposits. While some potential for the accumulation of coalbed methane may exist within the Mesaverde Formation, the economics of production would likely prove to less attractive than those for a more shallow target horizon.

The Mesaverde Formation is overlain by the Lewis Shale, which is marine in origin. The Lewis Shale also contains both sandy shale and some lenses of fine-grained sandstone (Dunlap 1958). The inclusion of clastic sedimentation is the direct result of episodic marine regression. The Lewis Shale is a correlative unit to the Pierre Shale to the east and the Bearpaw Shale in Montana. The formation thickens to the southwest and ranges in thickness from 200 feet (Mapel 1959) to about 470 feet in the southwest (Horn 1955).

Late-Cretaceous deposition in the eastern portion of the Powder River Basin resulted in the accumulation of a massive marine shale known as the Pierre Shale. The maximum gross thickness of the Pierre is in excess of 3,000 feet, which is found in Niobrara County, Wyoming.

Although some minor, discontinuous sandstone bodies are found within the Pierre, this formation cannot be regarded as a viable source of groundwater (Hodson et al 1973).

Upon the final withdrawal of the marine environment from the primordial Powder River Basin, sustained deposition of clastic material occurred along an erratic shoreline which was slowly migrating to the southeast. The resultant stratigraphy presents a sand mass which is increasingly younger in the direction of the regression. The Fox Hills Sandstone is considered to be a well-developed sandstone which is fine- to medium-grained and poorly cemented.

The Fox Hills Sandstone can produce significant amounts of groundwater with individual wells yielding up to 200 gallons per minute. Several wells are known to fow up 
to 75 gallons per minute from depths as great as 2,000 feet. One well, located in C'ampbell County, has a shut-in pressure of 54 pounds per square inch. Total dissolved solids range from 1,000 to 2,000 milligrams per Liter. Water chemistry is mixed with no prevailing ions (Hodson et al 1973).

The Fox Hills Sandstone is overlain by the Lance Formation. The Lance geologic section records the deposition of continental deposits following the complete withdrawal of the Upper Cretaceous sea in the Powder River Basin and represents the youngest Mesozoic strata found in the Powder River Basin.

The predominant lithology is sandstone; however, significant deposits of carbonaceous shales and some coals are also found in the Lance Formation. The coalbeds appear to have been formed along a stable, but swampy, coastline traversed by numerous aggrading stream channels. Bentonite deposits which are very common in the Lance suggest that volcanic activity was also a major element in the depositional environment.

Commercial develofment of Lance-age coal has been established in Converse and Natrona counties in Wyoming, along the southern perimeter of the Powder River Basin. Mines located near Glenrock have produced small amounts of subbituminous coal from the basal 200 feet of the Lance Formation (Mapel 1958). The upper part of the Lance Formation (Hell Creek in Montana) contains no coal. The Lance Formation is nearly 2,500 feet thick near Glenrock and thins to the north to approximately 500 feet thick in Big Horn County, Montana.

Groundwater resources within the Lance Formation are very limited and well yields are generally less than $\mathbf{2 0}$ gallons per minute. Most wells in this formation appear to have been located near the outcrop areas and may only be producing water from a small portion of the formation. Higher yields of groundwater may be realized through completion of wells across a more complete interval within the Lance. Total dissolved solids range from 2.00 
to over $2,000 \mathrm{mg} / \mathrm{L}$. Groundwater chemistry in the Lance is not dominated by any particular ion (Hodson et al 1973).

\section{Palocene and Eocence Are Deposition}

The remainder of the geologic section within the present Powder River Basin includes the Fort Union (Paleocene) and the Wasatch (Eocene) formations. Due to the close similarity between the depositional histories and the present economic association between these formations as coal-bearing strata, the geology and hydrology of these horizons are described in the following section on coal-bearing strata.

\section{PRINCIPAL COALBEARING STRATA}

Two principal coal bearing strata are found in the Powder River Basin. These are the Paleocene-age Fort Union Formation and the Eocene-age Wasatch Formation.

\section{Eort Union Formation}

The Fort Union Formation has a maximum gross interval thickness in excess of 6,000 feet near the basin axis in the vicinity of Buffalo, Wyoming. The Fort Union thins to the north, south and east from the Buffalo area. The Fort Union is comprised of three members which are, in ascending order, the Tullock, Lebo Shale and Tongue River. Of these three members, the Tongue River contains, by far, the most extensive reserves of coal and the thickest individual coalbeds in the Powder River Basin. (Figures 4, 5, 6).

\section{Tullock Member}

The Tullock Member overlies the Lance Formation (Hell Creek in Montana) and consists of sandstone, siltstone, mudstone, carbonaceous shale and coal. These sediments 
were deposited in a fluvial environment. Flores and Ethridge (1985) suggested that the dominant flow regime was to the north. Sediment was derived from the Bighorn, Laramie and Hartville uplifts (Law et al. 1991). Total thickness of the Tullock member ranges from 370 to 1,400 feet (Brown 1991) in the north central basin and nearly 2000 feet thick in the southwest (Curry 1971). There has been some cominercial development of the thin coals (less than 5.0 feet in thickness) which are found in the south-southwestern portion of the basin.

Hydrology

The occurrence of groundwater is not well documented within the Tullock Member.

\section{Lebo Shale Member}

The Lebo Shale, like the Tullock, contains sandstone, siltstone, mudstone, carbonaceous shale and some coal. The depositional setting includes both fluvial and lacustrine environments. This member is 150 to 400 feet thick, with the greatest thickness identified near the basin axis. Thick mudstones dominate the sedimentary profile of this member. The absence of thick clastic intervals suggests that subsidence of the ancestral basin, rather than uplift and subsequent erosion of surrounding structural highs, provided a structural setting for deposition during Lebo time (Curry 1971). Additional evidence supporting this hypothesis is found in the fact that Lebo sediments found near the base of the Laramie Range and the Bighorn Mountains have the lowest sandstone content in the entire basin. Coa! has been produced on a limited basis from this interval, primarily in the southern part of the basin.

\section{Hydrology}

The potential for production of groundwater from this member is minimal. 


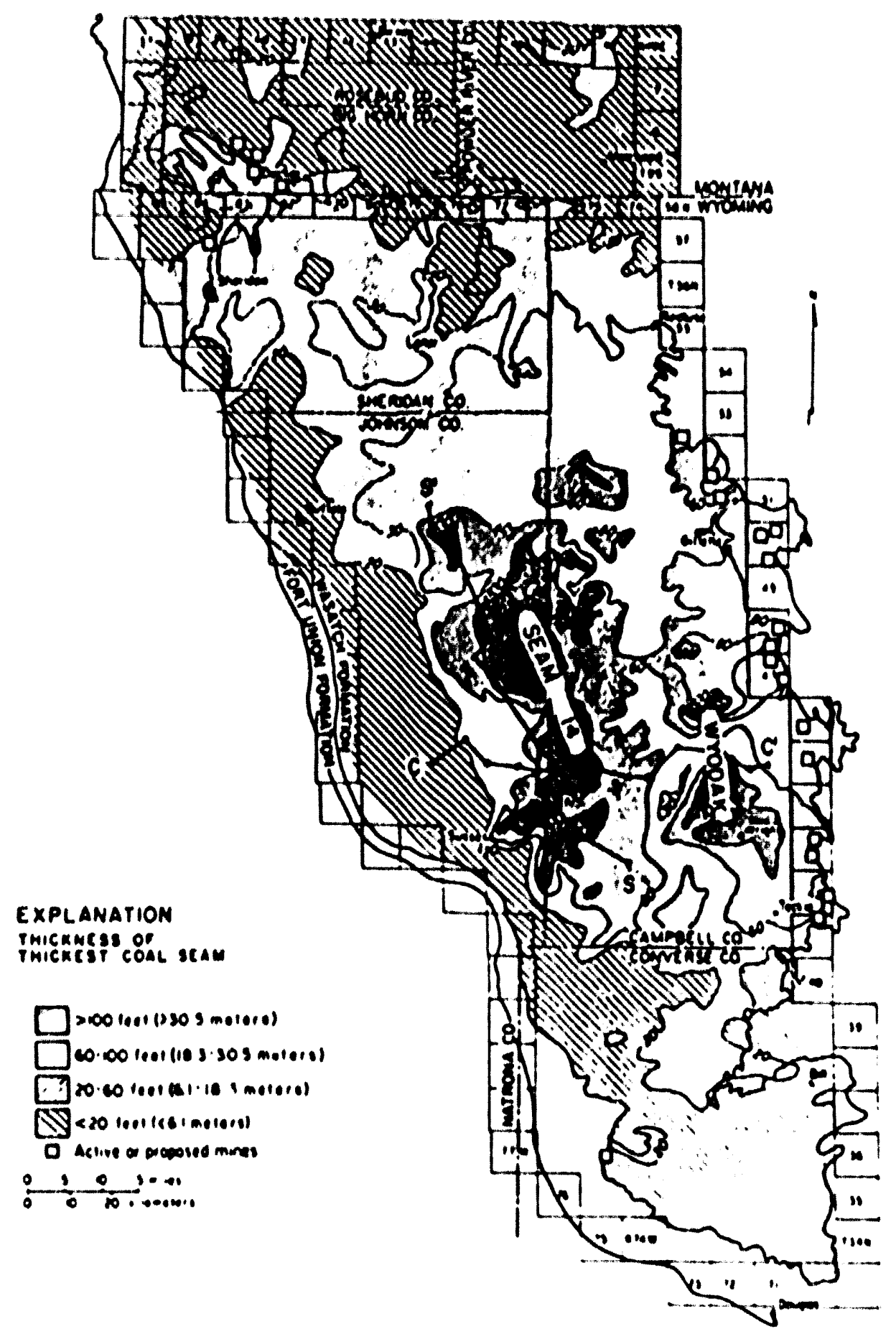

Figure 4. Maximum coal map for the Tongue River Member. The thick strike-parallel coal (Wyodak coal sequence) at the outcrop coincides with locations of surface mines. The second thick coal (seam 14), traversed by cross-section S-S', formed in an interdeltaic plain setting (Figure 3 ). The map was constructed by contouring the thicknesses of the thickest coal seam in each borehole. (after Ayers 1986). 


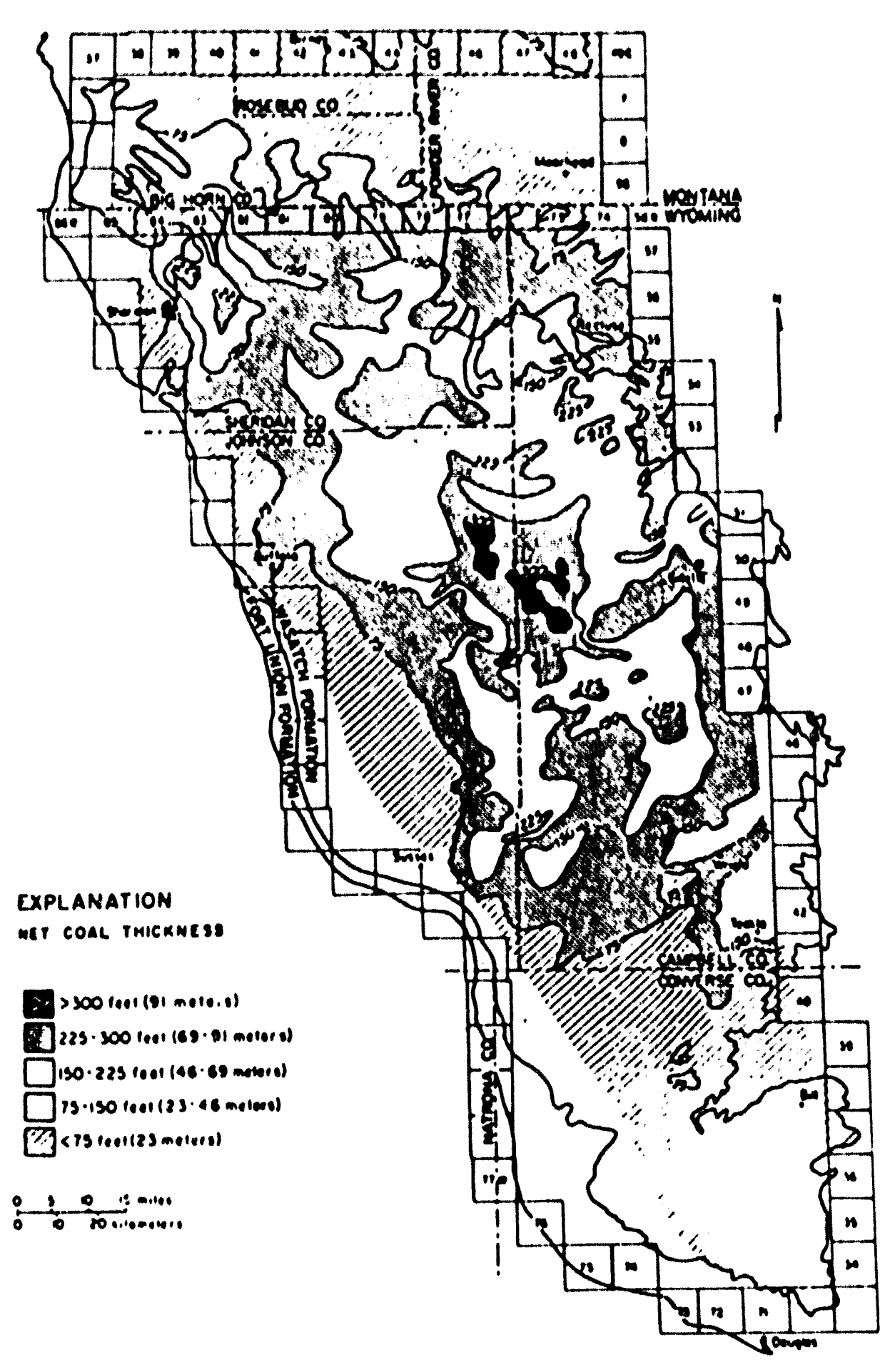

Figure 5. Coal isolith map showing that the net thickness of coal is greatest in the center of the Wyoming part of the basin and northeast of Sheridan, Wyoming. Net thickness is nearly zero between Buffalo and Sussex and between Douglas and Bill, Wyoming, which were areas of muddy lacustrine sedimentation. (after Ayers 1986). 


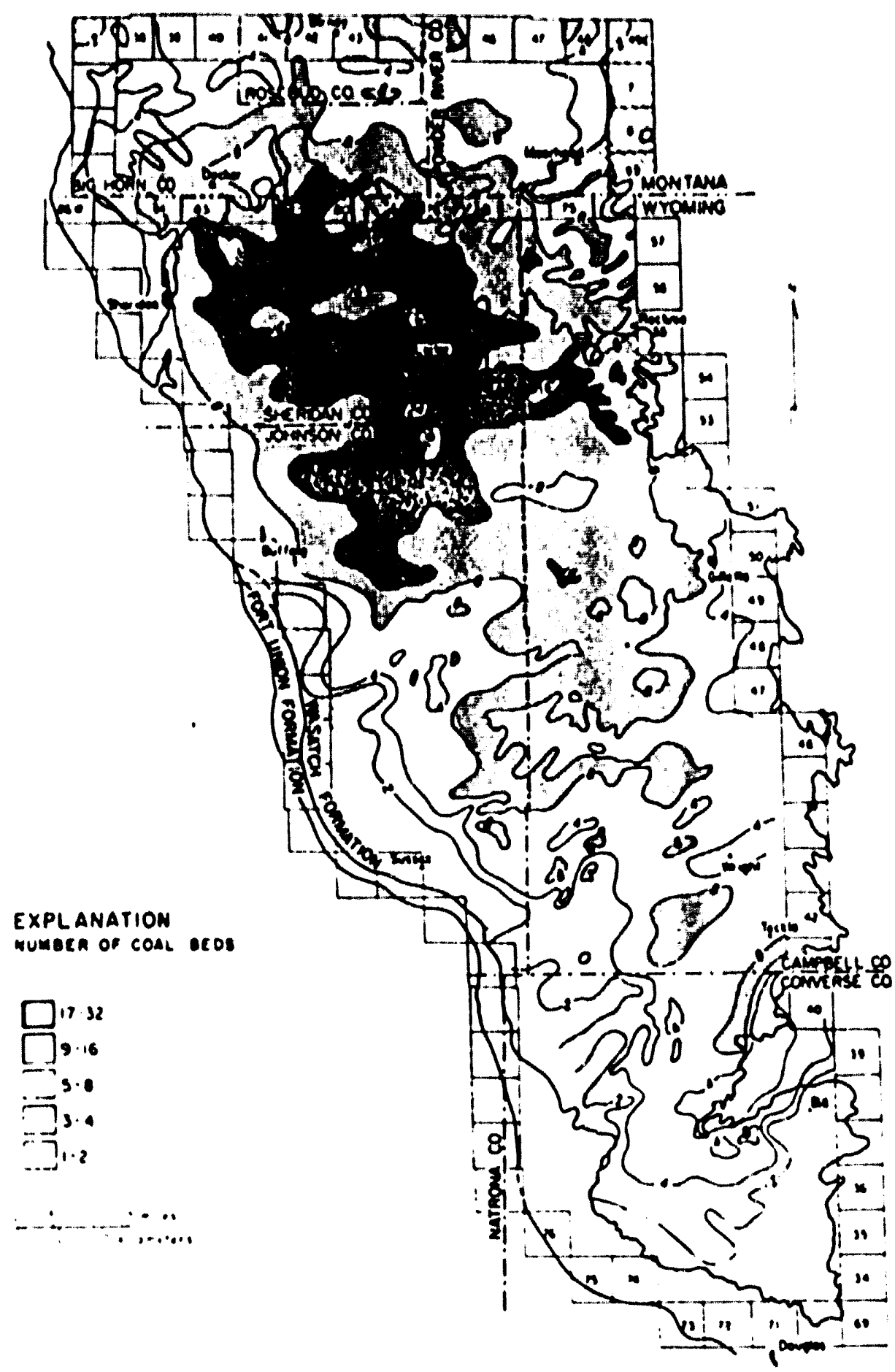

Figure 6. Coal isopleth map revealing that the greatest number of coal seams is in the north-central part of the basin. In the two areas of thick strike-parallel coals (Figure 9) there are fewer seams, but they have a greater average thickness (Figure 12). Few seams are present along the west and south margin of the basin. (after Ayers 1986). 


\section{Tongue River Member}

The Tongue River Member, which overlies the Lebo Shale, is dominated by deposition of sandstones and coal. The interval generally increases in thickness toward the north end of the basin. A pronounced increase in interval thickness toward the basin axis suggests that deformation associated with the Laramide orogeny was very active during Tongue River time. The Tongue River Member is at least 2,000 feet thick in southern Rosebud County, Montana, but thins southward to approximately 800 feet near Sheridan and to about 600 feet near Gillette, Wyoming (Mapel 1958). A sequence of fluvial deposits, both as fluvial-channel and fluvial-lake dominated facies, best describe the depositional environment of the Tongue River Member of the Fort Union Formation (Flores 1981).

Sediment types found within the Tongue River include sandstone, siltstone, shale, coal, carbonaceous shale, limestone and ironstone. The predominant sediment type is sandstone, which is found along with coal deposits. The number of individual coalbeds is difficult to ascertain, however the thickness of individual seams ranges from less than a foot to nearly 100 feet. The Wyodak-Anderson bed ranges in thickness from 50 to 100 feet. Individual coal seams are known to converge and diverge in the preserved sedimentary record. This observation appears to be consistent with the depositional model (proposed by Flores and others) which consisted of numerous coalescing and diverging fluvial channels bounded by poorly drained inter-channel bogs.

As mentioned earlier, two distinct environments have been inferred (Flores, 1981) from the sedimentary record. These are a fluvial-channel and a fluvial-lacustrine environment. In both settings, coal is derived from poorly-drained margin areas bordering

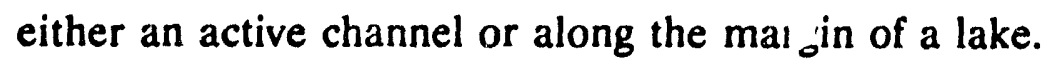

Those coal deposits associated with the fluvial channels are generally thicker and more laterally continuous than are those coals derived from lake margin deposits, where vegetation was periodically drowned by a temporary rise in lake water levels. These 
deposits tend to have numerous shale partings and individual coalbeds are also numerous but also very thin. By contrast, bogs and swamps which formed between numerous channels tended to be much more stable and extensive. Sediment influx was not generally widespread in these areas and was largely restricted to crevasse splay deposition along channel banks. As a result, vegetative material was allowed to accumulate and with time generate thick coal seams having very few shale partings.

\section{Wasatch Formation}

The Fort Union is overlain by the Wasatch Formation, an Eocene-age deposit very similar to the Fort Union in both depositional setting and lithologic character. The Wasatch consists of lenticular sandstone, fine- to coarse-grained, and interbedded shale and coal. The maximum thickness is reported to be 1,575 feet near the Pumpkin Buttes area in southwestern Campbell County, Wyoming. Coarse-grained clastics are generally thicker in the south portion of the basin. Toward the west, along the base of the Bighorn Mountains, the Wasatch grades into a thick conglomeratic sequence which is referred to as the Kingbury and Moncrief members of the Wasatch Formation. The documented occurrence of igneous and metamorphic rock fragments within these conglomerates, especially the Moncrief member, suggests the gradual uplift of the Bighorn Mountains and subsequent erosion of pre-Cambrian core rocks.

The thickest coal seam found in the Powder River Basin is contained in the Wasatch. The Healy, or Lake De Smet coal bed, which is found in the upper Wasatch, is nearly 220 feet thick near the town of Buffalo, Wyoming and over 100 feet thick at nearby Lake De Smet. In this same area, the Wasatch Formation has a maximum gross thickness of 1,500 feet. This thickness is also a maximum for Wasatch deposition in the Powder River Basin. Among the more significant coal seams found in the Wasatch are the Monument Peak, Walters, Healy, Cameron, Murry, Ucross and the Lake De Smet beds. In the Sheridan, Wyoming area four additional seams have been identified in the basal portion of the 
Wasatch. These were described by Culbertson and Mapel (1976) and named the Bar N, Burgess, Heppner and Wyarno seams.

\section{Hydrology}

A discussion of the hydrology of both the Fort Union and Wasatch Formations is presented in the discussion of Aquifer and Reservoir Distribution on page ??? of this report.

\section{OVERBURDEN STRATA}

Across most of the Powder River Basin, sediments deposited after the Wasatch Formation have been removed by erosion and, as a result, very little overburden remains. For example, the Fort Union-age coals mined near Wyodak in Campbell County, Wyoming lie beneath 10 to 30 feet of material. Much of the material exposed at the surface across the Powder River Basin is either Fort Union or Wasatch in age (Figure 3). In the central and western basin, the thick Fort Union coal seams are found at depths of as much as 1,200 feet.

\section{COAL AND COALBED METHANE - OCCURRENCE, OUANTITY IN-PLACE AND CHEMICAL, CHARACTERISTICS}

\section{COAL OCCURRENCE}

Following the final withdrawal of the marine depositional environment during Late Cretaceous time, the area now known as the Powder River Basin became dominated by marine margin swamps and tidal areas which evolved during Tertiary time into an fresh water channel and delta environment which resulted in clastic sedimentation. Flores (1981) has described a paleo-depositional setting which included the formation of numerous interchannel and lake-margin swamps and peat bogs across the incipient basin area which, he 
believes, resulted in the formation of the thick coal seams. In contrast to the model espoused by Flores, McClurg (1988) has proposed that the thick and laterally continuous coals found in the Powder River Basin "can best be explained by a series of interacting lacustrine/swamp ecosystems in a subsiding basin." McClurg sites the necessity for environmental stability in the formation of thick accumulations of peat. This stability, he contends, is lacking in the inter-channel swamp model of Flores.

Coal in the Powder River Basin is generally ranked as subbituminous $\mathrm{C}$ or Lignite. Some coal deposits found in the Tongue River member of the Fort Union Formation are ranked as subbituminous $B$ and, rarely, as subbituminous $A$. In general, these coals can be characterized as thermally immature. Coal with a ranking of subbituminous $B$ have a thermal output of at least 10,000 British Thermal Units or BTU's. Lignite falls below an output of 8,400 BTU's. Subbituminous $C$ has a range of thermal values between 8,400 and 9,500 BTU's. In general, coals in the Wasatch are lower in rank and thermal value than those in the Fort Union Formation.

The generation of coalbed methane is the direct result of a sequential process involving bacterial action, depth of burial and heat. Bacterial activity in an aerobic environment will first metabolize any free oxygen present in either plant remains or surrounding sediments. Other bacteria will metabolize sulfates, if present, and methane production will begin through bacterial respiration. Subsequent reduction of carbon dioxide and generation of additional quantities of methane follow as a consequence of anaerobic respiration. The biogenic generation of methane will continue until the buried material has attained an average temperature of around 50 degrees Centigrade. At this point, much of the original moisture will have been expelled and the coal will have attained an approximate rank of subbituminous (Rightmire, 1984). With increased temperature and additional time, the generation of coalbed methane, or methanogenesis, will continue as the coal matures and attains higher rank. Maximum generation of methane from coal occurs at a temperature of 150 degrees centigrade. 
The coals found in the Tertiary-age deposits of the Powder River Basin have not advanced beyond the rank of subbituminous and, as a result, the primary mechanism for methanogenesis in this area is binlogic. The net result of this fact is that while the amount of coalbed methane produced was probably not as great as in a more mature, higher-ranked coal, the total thickness of coal in the Powder River Basin provides a basis for the accumulation of very significant gross methane reserves.

\section{ESTIMATE OF COALBED METHANE RESERVES}

Current estimates of total coal resources in the Powder River Basin indicate that 1.0 trillion tons of coal remain in-place. Existing data on desorption of coalbed methane suggest that a ton of coal in Wyoming might contain anywhere from 5 to 100 cubic feet of methane. By simply multiplying the estimate of in-place resources by the two estimates of gas content, reserves of coalbed methane in the Powder River Basin may range between 5.155 and 103.1 trillion cubic feet.

Randall (1991) reports that production of coa'bed methane in the Powder River Basin was begun in 1916 with at least 20 shallow gas fields established in the Wyoming portion of the basin. The depth of productive intervals varies from 143 to 1842 feet and initial production is reported to be as high as 2,600 thousand cubic feet of gas per day (MCFGPD). Further, it is noted that much of this production originates from sandstones found adjacent to the Tertiary coals of the Tongue River Member of the Fort Union Formation (Paleocene). One field is reported to produce gas from the overlying Wasatch Formation (Eocene).

A direct correlation is observed between reservoir thickness and cumulative gas production. Thicker sandstones produce more gas and there is very little water production. In contrast, methane production from coalbeds tends to have a much higher potential for water production without significantly higher gas production. It does not appear that there 
is a direct correlation between coalbed thickness and higher cumulative production of methane gas.

The diminished potential for methane production directly from coalbeds, relative to the potential from adjacent sandstones, may be attributable to the biogenic nature of the gas and relatively lower permeability found in most coals. Permeability in coal seams is largely dependent upon the development of fractures or cleats.

The formation of secondary permeability in coal seams can be enhanced through the development of geologic structure and attendant deformation associated with folding, faulting or jointing (cleat development).

Production of coalbed methane in the Powder River Basin is often associated with compression folding of shallow (coal-bearing) strata occurring as a result of the structural deformation of the basin during the Laramide orogeny. Coalbed methane production established within the last three years has dernonstrated that water production can be reduced when produced reservoirs are structurally enhanced (Figure 7). Figure 7 (Law et al. 1991) depicts five different structural/stratigraphic trap scenarios. All of these possible traps assume the presence of an adequate seal, such as shale or mudstone. In general, compaction features such as these are based on contrasting compaction potential of different lithologies. Some of these structures exhibit as much as 250 feet of structural relief.

The first depicted trap model (A) is a simple anticlinal feature. It is important to note that stress fractures on the flanks of such a feature could significantly enhance the development of cleat permeability in the coal seam, thus increasing the potential for rapid desorption of gas from the coal and leading to more efficient production of coalbed methane.

The second trap model (B) is both structural and stratigraphic in nature. Methane gas would accumulate at the updip contact between the coal and a non-coal lithology. The 
third trap model (C) actually combines elements of the first two models and involves a change in coal quality, in essence a facies change between coal and shaly coal. The fourth type of trap model (D) is a structural feature which has been truncated by erosion, producing a situation very similar to that depicted in the second trap model. The fifth and final model (E) is possibly the most complex and involves the development of compaction faults. This last model may be more likely to occur along the flanks of the basin where the greatest deformational impact would be expected with relative proximity to the effects associated with the growth of major uplifts along the perimeter of the basin.

The accumulation of biogenic coalbed methane is highly dependent upon the early formation of a trap. Compaction folding, such as would be necessary in any of the trap scenarios already described, would have its greatest impact on unconsolidated or unlithified sediment and could then provide a suitable environment for the accumulation of coalbed methane at the most optimal time.

\section{PRODUCTION OF COALBED METHANE FROM TERTIARY-AGE COALS}

The production of coalbed methane occurs through the release or desorption of methane from the coal. Relative to other reservoir rocks, coal has an enormous internal surface area which is capable of storing an estimated 3 to 7 times the amount of methane that more conventional reservoirs can store at similar depths and pressures.

Desorption of coalbed methane is controlled by the moisture content of the seam and dewatering of the seam is often required to stimulate the process through removal of the hydrostatic pressure or head.

Established production of coalbed methane in the Powder River basin has indicated that much of the methane is produced from sandstone reservoirs which are adjacent to the ccal seams (Figure 8). It has been noted that water production associated with this methane is generally very low from these sandstones, while gas production directly from the coal 

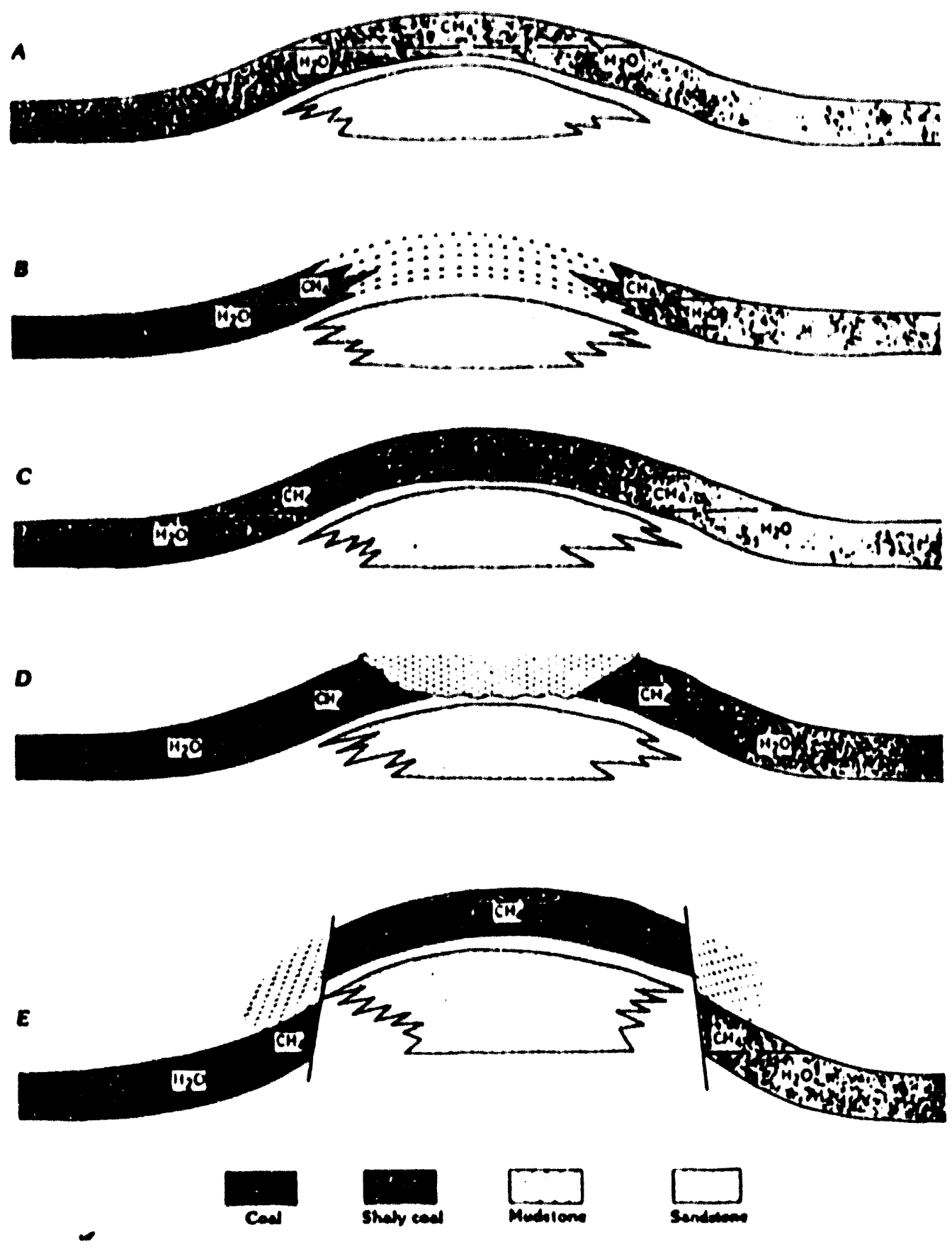

Figure 7. Diagrammatic sections of gas traps that may be associated with compaction folding (after Law et al 1991). 


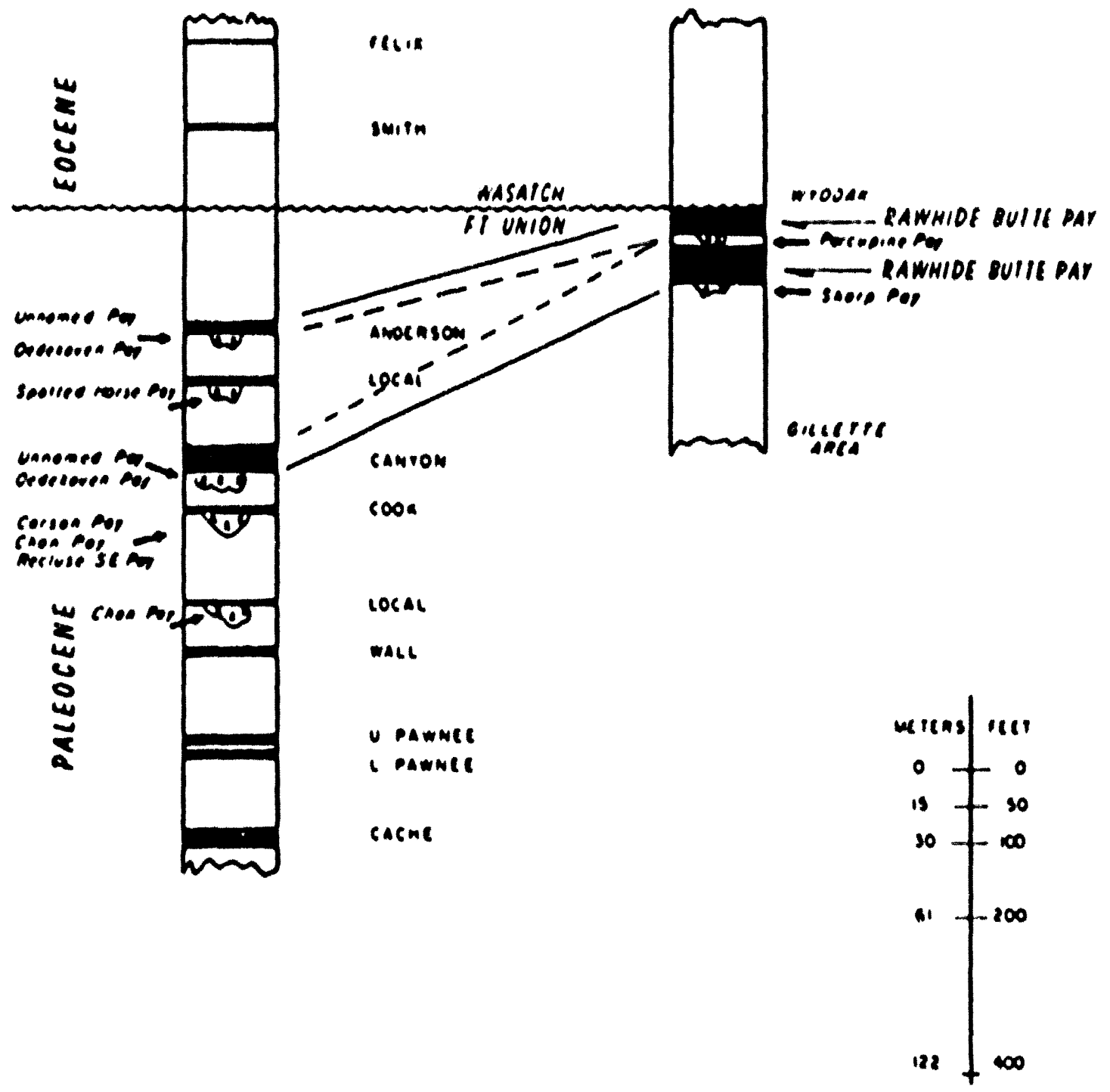

Figure 8. Stratigraphic columns of $\mathrm{Ft}$. Union \& Wasatch coalbeds in Campbell County (after Randall 1991). 
tends to result in significantly higher water production with a decreased volume of gas.

In developing new gar production, the operator should consider initial production from sandstones adjacent to coal seams. Based on the history of existing production, methane can be expected without significant procluced water and reduction of gas pressure in the sandstone reservoir may enhance additional desorption of gas from the adjacent coal. A second phase of production can be initiated when gas production from the sandstone reservoir has been attenuated to marginal levels. Water production from the coal might be disposed of through injection into the previously produced sandstone reservoir. In addition, the general water chemistries of the adjacent strata should be very similar and compatibility of the injected water should not be a concern.

\section{AOUIFER ANDRESERYOIR DISTRIBUTION}

Much of the groundwater presently being utilized in the Powder River Basin supplies stock and domestic afplications. These wells are generally completed at depths less than $\mathbf{5 0 0}$ feet in numerous sandstone intervals within the Tertiary-age Fort Union Formation which are quite localized and very discontinuous. For this reason, correlation of producing zones between wells is very difficult. In recognition of this fact, hydraulic-head data from individual wells is of limited value in the definition and evaluation of predominant groundwater flow regimes in the basin. Groundwater chemistry can be very useful in isolating recharge/discharge systems associated with specific aquifers and may also prove valuable in gauging the impact of gas production on local groundwater systems.

Structural controls, most specifically the gross geometry of the basin, would suggest a prevailing northward flow of deeper groundwater supplies and data presented by Daddow (1986) is consiste $n$ with this observation (Figure 9). A potentiometric-surface map was produced for wells completed in the Wyodak-Anderson coal seam which indicates recharge of this aquifer along the outcrop belt located in the southern portion of the basin and flow is to the north/northwest. An area of groundwater discharge has not been specifically 
identified in the northern basin. The Wyodak-Anderson seam is found in the upper portion of the Tongue River Member of the Fort Union Formation.

Rankl and Lowry (1990) concluded that in the apparent absence of discharge areas in the northern basin, as identified on the basis of water chemistry. "the regional now system may have a smaller flow than previously thought, and that measurable effects from surface mining and water development will affect mostly local now systems." Figure 10 depicts the operation of local components as elements with in a basin-wide now regime.

It is very important that a more thorough understanding of local groundwater now within an area targeted for methane gas production should be developed prior to the commencement of production activities. It may be possible 10 impose limits on water production by selecting locations for producing wells in arcas where groundwater now is most compatible with the production of coalbed methane.

Water quality in the basin is quite variable and ranges from fresh to brine. Chemical quality for groundwater produced from the Wasatch-Fox Hills interval is depicted in Figure 11. The distribution of sodium and potassium, calcium and magnesium, carbonate and bicarbonate, and sulfate are shown with regard to depth of the producing interval. The most notable chemical variations are significantly higher sulfates in waters produced from depths of less than 500 feet. Sulfate concentrations in water samples collected from wells producing from the interval of 501 feet to 600 feet indicate an average of 12 milliequivalents per Liter (meq/L), compared with increasingly higher concentrations for more shallow well completions. Concentrations of calcium and magnesium decrease from $18 \mathrm{meq} / \mathrm{L}$ to less than $2 \mathrm{meq} / \mathrm{L}$ for water produced from a depth interval of 501 feet to $600 \mathrm{feet}$ as compared with water produced from 1 feet to 100 feet. No explanation has been found for the observed decrease in the concentration of total cations and anions down to a depth of approximately 500 feet. 


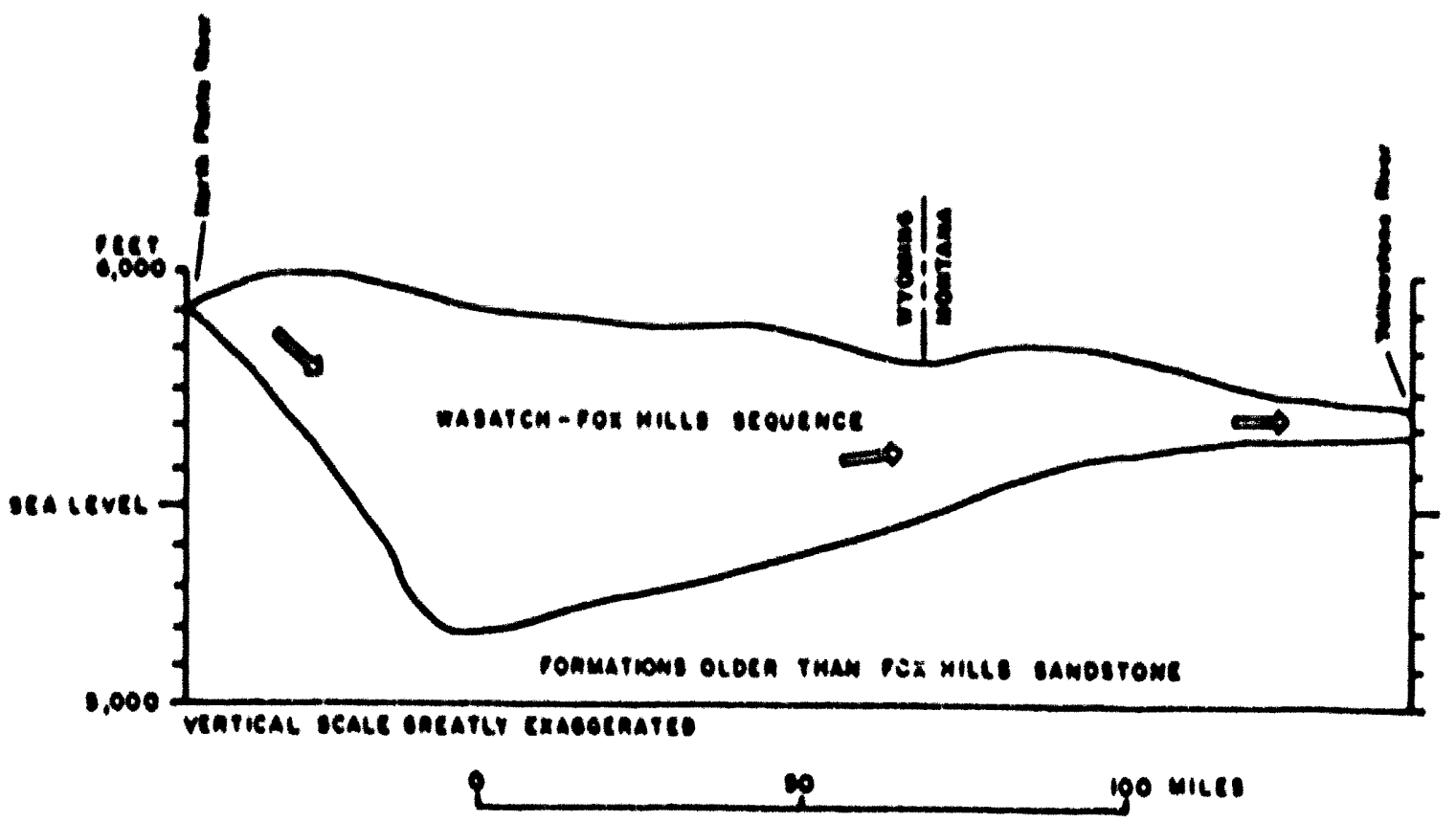

Figure 9. Regional groundwater now (arrows) controlled by stratigraphy. Section is along 106. west longitude. from the North Platte River in Wyoming to the Yellowstone River in Montana.

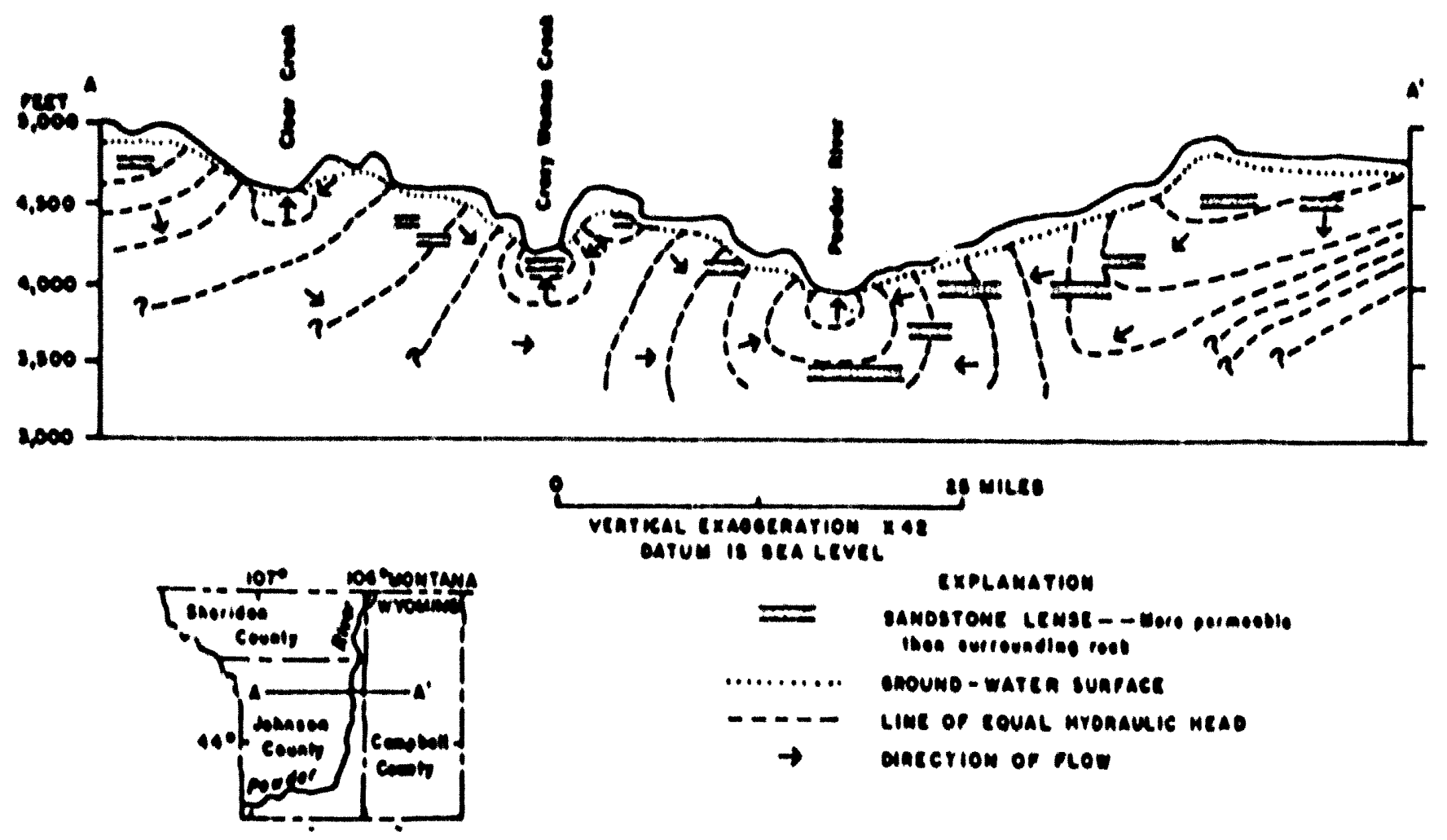

Figure 10. Regional groundwater flow into major streams. (Modified from Hagmaier, 1971. ig. 15.)

(Both Figures adopted from Rankl and Lowry 1990). 


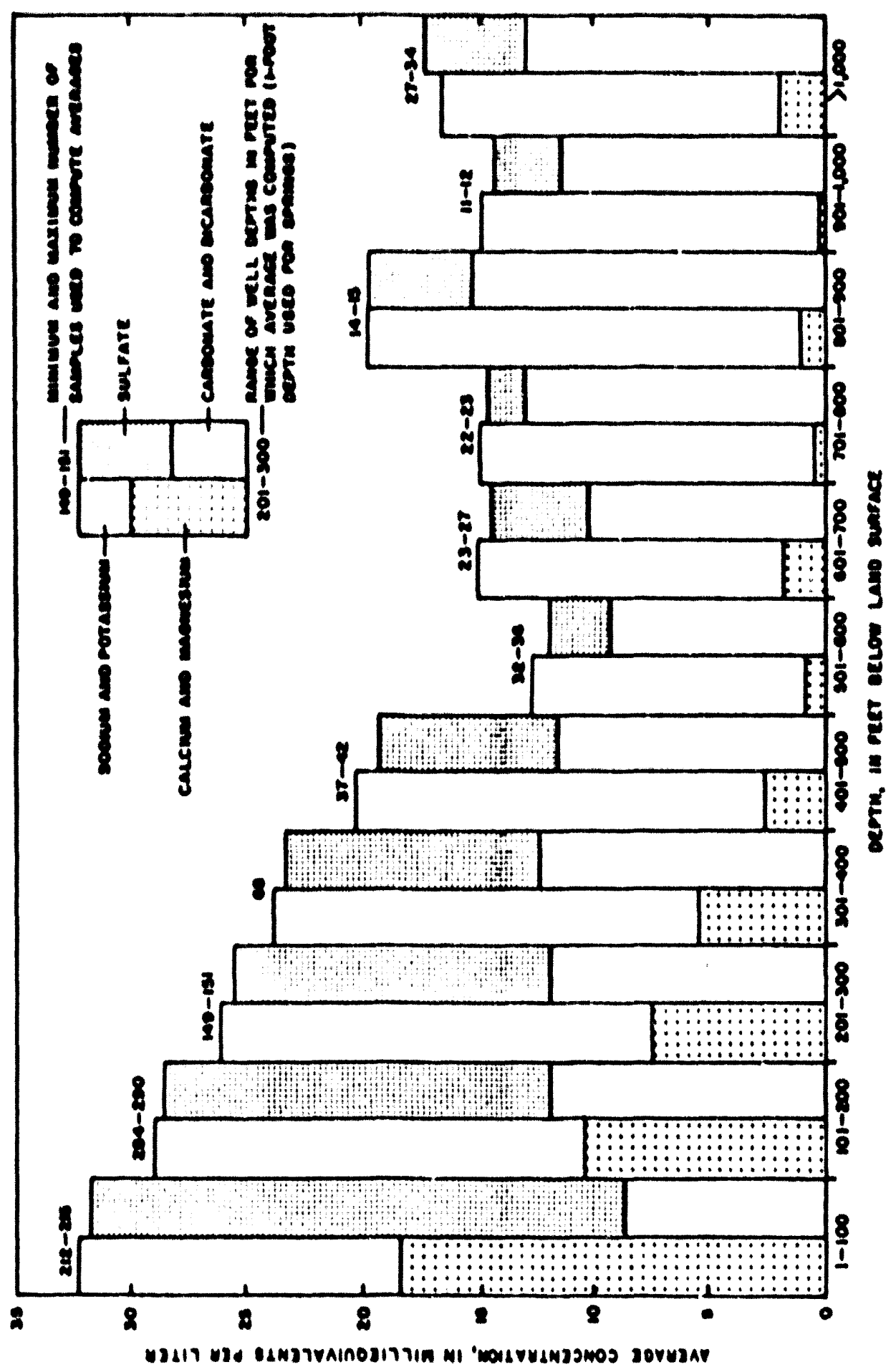

Figure 11. Differences in the chemical quality of water with depth in the Wasatch-Fox Hills sequence (after Rankl and Lowry 1990). 
Aquifer conditions within coalbeds are primarily unconfined near the outcrop area, the principal zone of recharge. Further west, into the basin, these coal aquifer(s) become confined as the presence of overlying clays creates a barrier, or aquitard, which restricts the downward infiltration of meteoric waters.

In general, groundwater is normally unconfined within the Wasatch Formation, while aquifers in the underlying Fort Union are more commonly confined.

A relationship has been established (Davis 1976) between aquifer conditions and the chemical quality of the water within the aquifer. Generally, calcium-magnesium sulfate waters predominate in the unconfined portions of coalbed aquifers, while sodium bicarbonate waters are most common under confined aquifer conditions in the coalbed aquifers.

An important observation has also been by Choate et al. (1984) regarding the presence of methane in artesian wells. Methane gas, originating in the Fort Union Formation, has been identified in substantial quantities within groundwater from many flowing artesian wells in the Powder River Basin. Due to the possibility that methane gas lift may provide the impetus for groundwater flow, the potential value of these wells as an exploratory tool becomes evident. Published information points out that there are at least 198 flowing artesian wells within the known subsurface extent of the Fort Union Formation. A majority of these wells, 139 to be exact, are located in eastern Sheridan and northeastern Johnson Counties in Wyoming. An area in northern Campbell County has also been identified as having a high concentration of shallow test holes and wells which are reported to produce anomalously high levels of methane gas. A total of 29 flowing artesian wells were identified in this area (Figure 12). 


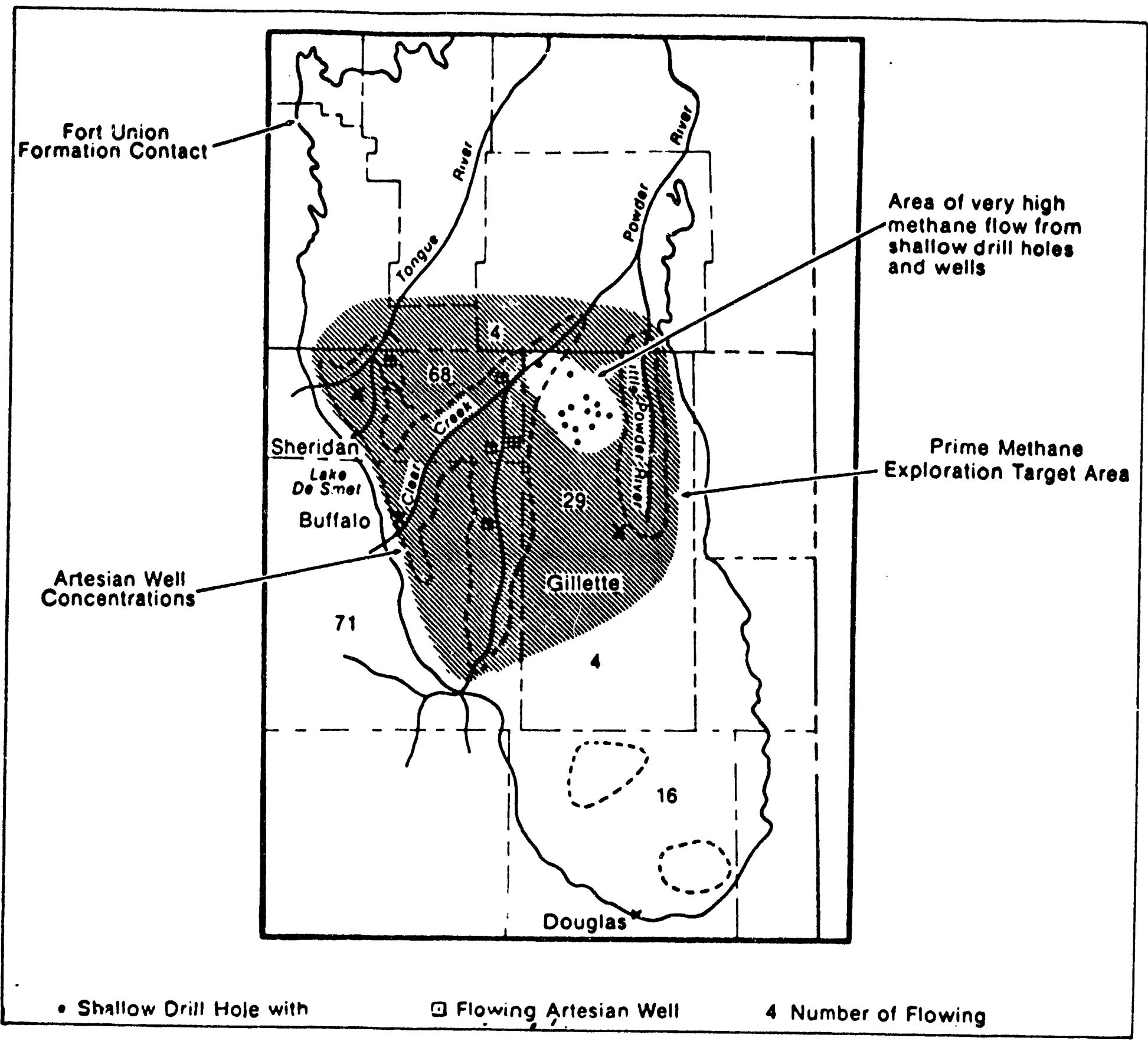

Figure 12. Methane exploration target area in Tongue River member of the Fort Union Formation (after Choate et al 1984). 


\section{EORMATIONS ACCEPTING DISPOSAL OF PRODUCED WATER}

The stratigraphy of the Powder River Basin includes significant accumulations of shales below the primary coal-bearing formations, the Fort Union and the Wasatch. Clastic deposition does occur within the Cretaceous-age Lance Formation, and the Lance does not yield more than 20 gallons per minute from producing wells. Thicker sandstones in the lower Lance, which represent fluvial deposits, may offer some potential as a recipient reservoir for produced water associated with the production of coalbed methane. The Lance Formation is nearly 2,000 feet thick near Buffalo, Wyoming. It may be possible to locate thick sands in the basal Lance Formation in this area which may offer opportunities for underground injection of produced water. No specific water chemistry type is dominant in groundwater from the Lance. On this basis, compatibility of produced water for disposal in this formation does not appear to be a matter for concern.

The Lance Formation is underlain by the Fox Hills Sandstone, which is capable of producing up to $200 \mathrm{gpm}$. Like the Lance Formation, the water chemistry of the Fox Hills Sandstone is not dominated by any particular ion or ions and may be compatible with groundwater produced in association with coalbed methane. The Fox Hills has a maximum gross thickness of 700 feet in the southwest part of the basin and is known to thin to the north and northwest, where it is often not differentiated from the overlying Lance Formation (Hodson et al 1973). Because this formation can produce significant quantities of groundwater (refer to discussion on Hydrology on page 12), opportunities for water disposal within the Fox Hills should be regarded with caution.

The Fox Hills Sandstone is underlain by nearly 7,500 feet of sedimentary rock consisting largely of shale, with some thin and discontinuous sandstones (Figure 2). The Tensleep Sandstone, which is Pennsylvanian in age, may represent the next available disposal reservoir. The Tensleep is over 300 feet thick in the western portion of the basin. The correlative unit in the eastern basin is the Minnelusa Formation, which is principally 
limestone. The depth of this formation, relative to potential coalbed methane production, and the possibility for artesian flow of the Tensleep aquifer may preclude consideration of underground injection into this formation.

The most promising horizons for the disposal of produced water appear to be the sandstone intervals which are adjacent to the coal horizons within the Tertiary Fort Union Formation.

No published information was found during the literature search regarding current underground water disposal practices in the Powder River Basin. The most widely utilized disposal option is aboveground in surface impoundments. 


\section{SUMMARY}

The Powder River Basin is a broad, asymmetrical feature formed as the result of the uplift of surround structural elements during the Laramide orogeny. The development of the Black Hills uplift and the Bighorn Mountains provided a source of clastic sediment which eventually filled the present basin area and also provided a substrate for heavy vegetative growth in a broad deltaic environment. The accumulation of vegetative matter in the early basin culminated in the development of the most extensive coal deposits found in the United States.

The coals of the Powder River Basin are considered thermally immature and are generally graded as subbituminous $\mathrm{C}$ or less. While these deposits do not contain the high methane concentrations associated with more mature coals in other basins, the abundance of numerous and often thick coal seams in the Powder River Basin offer substantial potential for the accumulation and possible development of large total volumes of coalbed methane.

Water is a recognized obstacle in the development of this potential resource; however, the application of Jack W. McIntyre's patented production process may be found to be most appropriate in the Powder River Basin. The process is designed specifically to separate produced water and produced gas in a downhole environment and may allow for more efficient and economical development of coalbed methane resources in this area. Through the application of a two-phased production approach, with initial production in the relatively water free sandstones adjacent to the numerous coalbeds and secondary production from the coals where water is much more abundant, it may be possible to maximize production potentials with a minimum of expense to the operator and with very limited environmental impact, when compared to surface disposal or deep underground injection disposal methods. 
The compatibility of water produced from the coalbeds with waters found within the adjacent sandstone horizons should not be a problem as sodium sulfate is the predominant water type throughout the coal-bearing Fort Union Formation. Water from the overlying Wasatch Formation can be expected to exhibit a much greater variability in chemical quality which may be considered incompatible with water in deeper horizons and may preclude their viability as receptors for disposal purposes.

\section{ACKNOWLEDGEMENT}

The author wishes to express thanks to the United States Department of Energy (DOE) for funding this work. The grant was awarded to Jack W. McIntyre under DOE Contract No. DE-FG46-92R699202. Mr. McIntyre contracted Geraghty \& Miller, Inc. to perform the research.

\section{DISCLAIMER}

Mention of specific brand names or models of equipment is for information only and does not imply endorsement of any particular brand. 


\section{REFERENCES}

Ayers, W.B. Jr., Coal Resources of the Tongue River member of the Fort Union Formation (Paleocene), Powder River Basin, Wyoming and Montana, Geologic Survey of Wyoming: Report of Investigations No. 35, 1986.

Baars, D.L. etal, "Basins of the Rocky Mountains Region: North American Craton: U.S. : Boulder, Colorado", The Geological Society of America, 1988.

Blackstone, "Compression as an Agent in Deformation of the East-Central Flank of the Bighorn Mountains, Sheridan \& Johnson Counties, Wyoming: Contributions to Geology", University of Wyoming, Volume 19, No., 2, 1981.

Bropst, D.A. and Epstein, V.B., "Geology of the Fanny Peak Quadrangle, Wyoming-South Dakota, Chapter 1, in Geology and Uranium Deposits of the Southern Black Hills", U.S.G.S. Bulletin 1063, 1963.

Brown, J.L., "Sedimentology and Depositional History of the Paleocene Tullock Member of the Ft. Union Formation, Powder River Basin, Wyoming and Montana, U.S.G.S. Bulletin 1917, 1991.

Brown, J.L., "Sedimentology and Depositional History of the Paleocene Tullock Member of the Ft. Union Formation, Powder River Basin, Wyoming and Montana", U.S.G.S. Bulletin 1917, 1991.

Choate, R., Johnson, C.A. and McCord, J.P., "Geologic Overview, Coal Deposits and Potential for Methane Recovery from Coalbeds-Powder River Basin, Coalbed Methane Resources of the United States", AAPG Studies in Geology Series No. 17, 1984.

Connor, G.W., "the Lance Formation-Petrography and Stratigraphy, Powder River Basin, Nearby Basins, Wyoming and Montana, U.S.G.S. Bulletin 1917 Part I, 1992.

Culbertson, W.C. and Mapel, W.J., "coal in the Wasatch Formation, Northwest Part of the Powder River Basin near Sheridan, Sheridan County, Wyoming in Landon River Basin, Curry, W.H. and Runge, J.S. eds, Geology and Energy Resources of the Powder River", Wyoming Geological Association, 28th Annual Field Conference Guidebook, 1976.

Curry, W.H. III, "Laramide Structural History of the Powder River Basin, Wyoming", Wyoming Geological Association Guidebook, 28th Annual Field Conference, 1971.

Davis, Richard W., "Hydrologic Factors Related to Coal Development in the Eastern Powder River Basin", Wyoming Geologic Association Guidebook, pgs. 203-207, 1976. 
Denson, N.M. etal, "Tectonic Map of the Hartville Uplift \& Adjacent Regions", Wyoming Geological Association Guidebook, 4th Annual Field Conference, 1949.

Dunlap, C.M., "The Lewis Fox Hills and Lance Formations of Upper Cretaceous Age in the Powder River Basin, Wyoming", Wyoming Geological Association Guidebook, 13th Annual Field Conference, 1958.

Flores, R.M. and Ethridge, F.G., "Evolution of Intermontane Fluvial Systems of Tertiary Powder River Basin, Montana and Wyoming", SEPM Rocky Mountain Paleogeographic Symposium, 3rd, 1985.

Flores, R.M., "Coal Deposition in Fluvial Paleoenvironments of the Paleocene Tongue River Member of the Ft. Union Formation, Powder River Area, Powder River Basin, Wyoming and Montana in Models for Exploration", SEPM, Special Publication \#31, 1981.

Hodson, W.G., Pearl, R.H., and Druse, S.A., Water Resources of the Powder River Basin and Adjacent Areas, Northeastern Wyoming, United States Geologic Survey, Reston, Virginia, 1973

Horn, G.H., "Geologic and Structure Map of the Sussex and Meadow Creek Oil Fields and Vicinity, Johnson and Natrona Counties, Wyoming", Oil and Gas Investing, Map OM $164,1955$.

Jenkens, M.A. and McCoy, M.R., "Cambro-Mississippian Correlations in the Eastern Powder River Basin, Wyoming and Montana", Wyoming Geological Association Guidebook, 13th Annual Field Conference, 1958.

Law, B.E., Rice, D.D. and Flores, R.M., "Coalbed Gas Accumulations in the Paleocene Ft. Union Formation, Powder River Basin, Wyoming", 1991.

Love, J.D., "Geology of the Powder River Basin, Northeast Wyoming, Southeast Montana in Basins of the Rocky Mountain Region", GSA, Geology of North America, V. D-2, pgs. 204-217, 1989.

Mapel, W.J., "Coal in the Powder River Basin", Wyoming Geological Association Guidebook, 13th Annual Field Conference, 1958.

Mapel, W.J., "Geology of Coal Resources of the Buffalo-Lake de Smet Area, Johnson \& Sheridan Counties, Wyoming", U.S.G.S. Bulletin 1078, 1959.

McCoy, M.R., "Ord. Rocks of the Northern Power River Basin and Blackhills Uplift Areas, Montana, Wyoming and South Dakota", Wyoming Geological Association Guidebook, 13th Annual Field Conference, 1958. 
Meissner, F.F., "Cretaceous and Tert. Coals as Sources for Gas Accumulations in the Rocky Mountain Area in Hydrocarbon Source Rocks of the Greater Rocky Mountain Region", RMAG Symposium Guidebook, pgs. 401-431, 1984.

Randall, A.G., "Shallow Tertiary Gas Production, Powder River Basin, Wyoming: in Proceedings of the 1991 Coalbed Methane Symposium", The University of Alabama at Tuscalooga, May 13-16, 1991.

Rankl, J.G. and Lowry, M.E., "Ground-Water Flow Systems in the Powder River Structural Basin, Wyoming and Montana", U.S. Geological Survey Water-Resources Investigations Report 85-4229, 1990.

Robinson, C.S. etal, "Stratigraphy and Structure of the Northern \& Western Flanks of the Black Hills Uplift, Wyoming, Montana \& South Dakota", U.S.G.S. Professional Paper 404, 1964. 

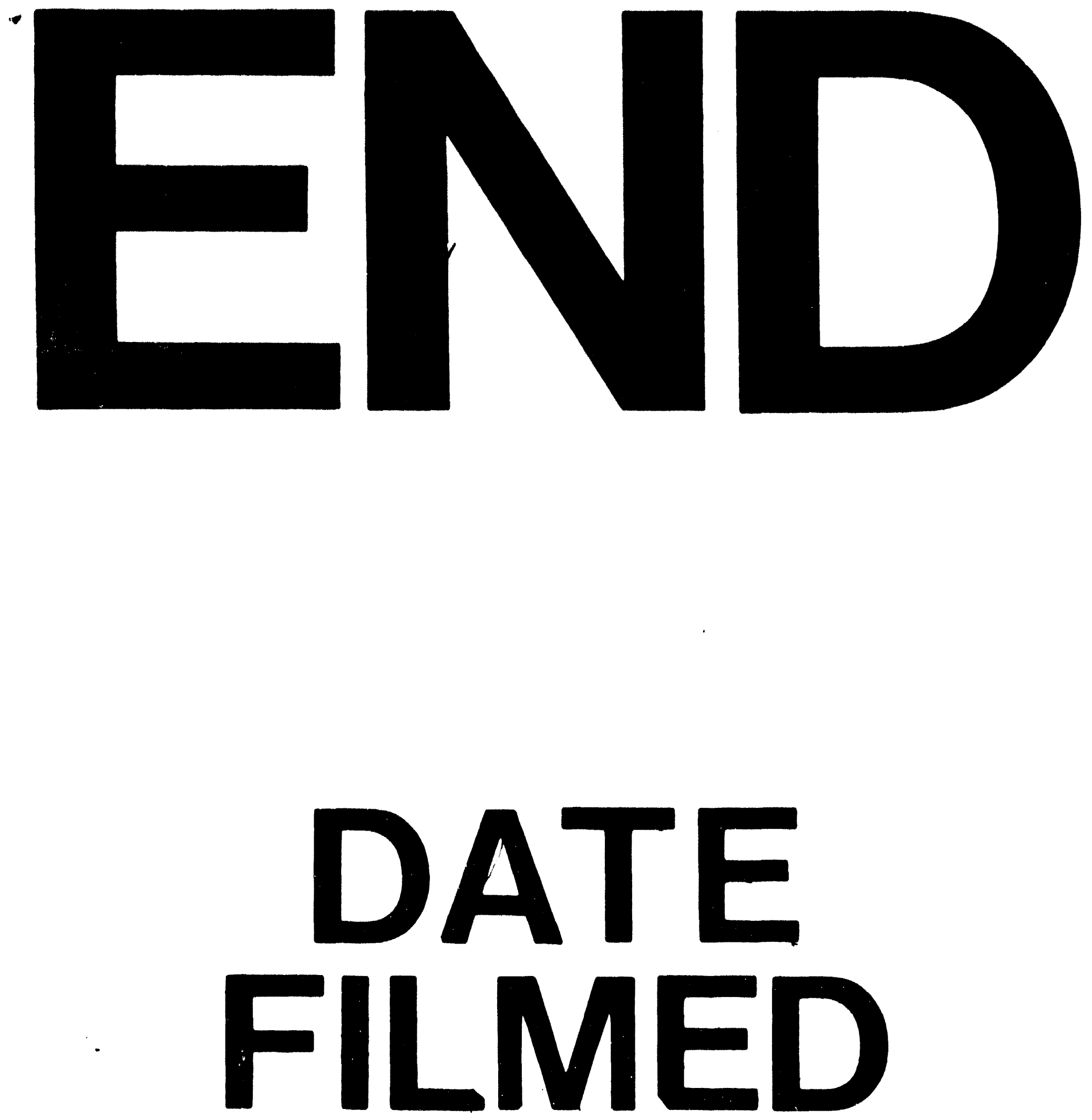

1

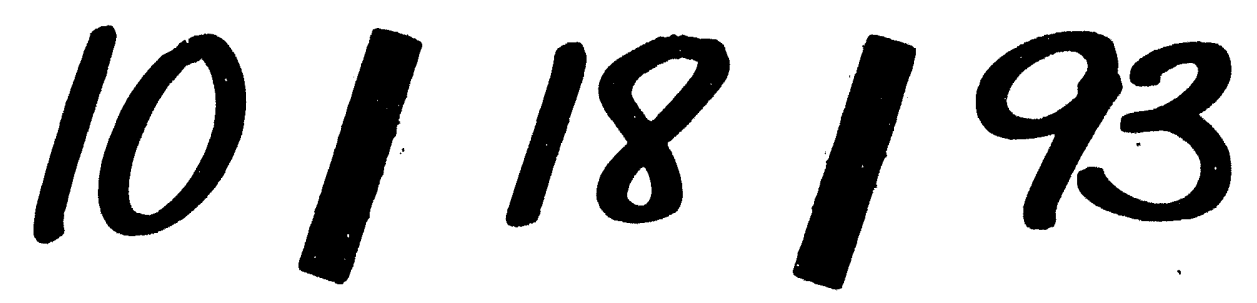


